\title{
35. HUMIC COMPOUNDS AND KEROGENS IN CORES FROM BLACK SEA SEDIMENTS, LEG 42B - HOLES 379A, B, AND 380A
}

\author{
A.Y. Huc, B. Durand, and J.C. Monin, Institut Français du Pétrole, Division Géologie, France
}

\begin{abstract}
Samples from Sites 379 and 380 (DSDP Leg 42B) in the Black Sea have been analyzed for their organic content. Subbottom depth of samples ranges from 4 meters to 621 meters at Site 379 (ages to 600,000 years B.P.) and from 600 meters to 1063 meters at Site 380 (ages from 750,000 to $3 \times 10^{6}$ years B.P. or more). The main organic fractions consist of humic compounds and of alkali-insoluble material, called humin, including its non-hydrolyzable fraction, kerogen.

The genetic properties of humic acids show great variety in the sedimentary columns suggesting important changes in the input of parental organic matter (autochthonous versus allochthonous [land derived] balance) during the course of sedimentation.

Moreover it is observed that organic matter changes as a function of burial, i.e., we observe: a decrease in the hydrolyzable fraction, a decrease in humic compounds content, a decrease in proteinaceouslike material in humic acids (amide bond vibrations in IR spectra disappear with increasing sample depth) and a decrease in the oxygen content in the more autochthonous-derived humic acids, while the more land-derived humic acids undergo burial without such a decrease. This fact suggests various ways of oxygen incorporation in the different kinds of humic acids. All these changes lead the bulk of the organic matter towards the kerogen status as it is found in ancient sediments. As a result, from the comparison between Sites 379 and 380 we might claim that kerogen formation has terminated at the deepest samples of Site 380, while it is still occurring at Site 379.
\end{abstract}

\section{INTRODUCTION}

Using previous research to compare the main properties of organic matter from both shallow young sediments (buried at depths less than $10 \mathrm{~m}$ ) and ancient sediments, great differences appear. In young deposits, besides a very low fraction of organic matter soluble in ordinary organic solvents, alkali soluble organic matter is high in most cases (Rashid and King, 1970; Nissenbaum et al., 1972). The remaining insoluble fraction (humin) cannot be studied with any validity because of the destruction of most of it during kerogen isolation using acids. On the other hand, in ancient sediments the extractability of organic matter by alkalis is low, and extractability by organic solvents which is low in the immature stage may be high in the catagenetic stage. Here the insoluble organic matter is practically not destroyed by kerogen isolation. Moreover, other differences occur in the properties of the organic matter. For instance, the oxygen content of humic acids is generally higher in young sediments than in ancient ones.

Changes in sedimentary organic matter, leading from young to older sediment status during the course of a sedimentary cycle, previously have not been detected because of a lack of sampling for geochemical purposes. However, these changes may be detectable in long cores such as those obtained by the Deep Sea Drilling Project. The JOIDES project in the Black Sea is well suited to such an attempt, which is outlined here. In this respect the humic compounds are considered to be the most suitable fraction of the sedimentary organic matter. They are obtained by a non-degradating procedure and are abundant in young sediments. Previous research has shown that they make up a substantial fraction of the sedimentary organic matter (Huc and Durand, 1973; Huc and Durand, 1977). However, it should be noted that in sediments the detrital input might imply the presence of evolved allochthonous organic matter which is derived from weathering and erosion of more ancient sediments, or of crystalline and metamorphic rocks. This evolved organic matter may amount in some cases to a large proportion of the total sedimentary organic matter (Debyser et al., in press). The methods used here do not provide information about such a fraction. In this respect it would be worthwhile to complete the present study by optical and electron diffraction analyses of the organic matter.

\section{SAMPLES}

The samples were taken from Holes 379A, B and $380 \mathrm{~A}$, which were drilled during DSDP Leg 42B, in the 


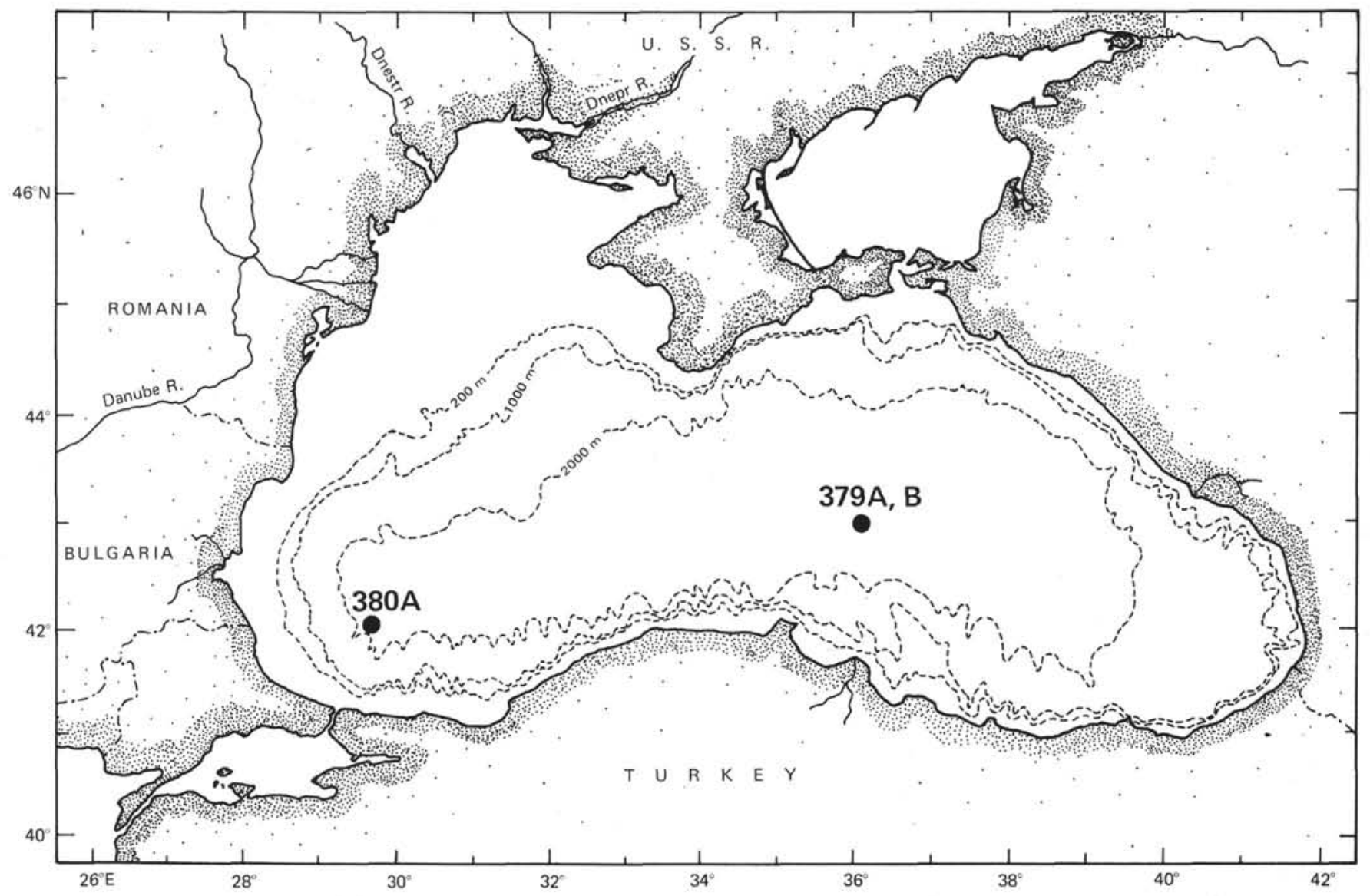

Figure 1. Location of the geochemical sites $(379 A, B$ and $380 A)$. The age at the base of Site 380 may be as old as late Miocene.

Black Sea (Figure 1). The sedimentological units in Figure 2 are taken from the Leg $42 \mathrm{~B}$ Shipboard Report.

Sixty-six samples selected for this study (Figure 2) were frozen on board ship then freeze-dried in "Institut Français du Pétrole" laboratories. In order to check the scattering of some values (organic carbon, mineral carbon) in samples close to each other, we have divided the samples into fractions (Table 1)

\section{EXPERIMENTAL METHODS}

The freeze-dried sediments were crushed for 5 seconds with an AUREC device. The following procedure was performed on homogeneous samples.

\section{Methodology for Total Organic Matter}

Organic and mineral carbon analysis are performed as follows: the sediment is treated with $2 N$ hydrochloric acid and mineral carbon value is obtained by titration of the solution after treatment. Organic carbon is analyzed in the washed and dried residue with a Leco analyzer. Hydrolyzable organic carbon is obtained by refluxing the sediment 16 hours in $6 \mathrm{~N} \mathrm{HC1}$. The organic carbon values in the remaining insoluble residue (corrected for sediment weight loss) is then compared with the total organic carbon.

\section{Methodology for Humus and Kerogens (Figure 3)}

Bitumens are extracted from sediments, using $\mathrm{CHCl}_{3}$. Then the samples are treated with $2 \mathrm{~N} \mathrm{HCl}$ at room temperature to dissolve carbonates. Humic compounds (FA + HA) were extracted from 19 samples using a $0.1 \mathrm{~N}$ sodium hydroxyde, $1 \%$ sodium pyrophosphate solution. Humic acids (HA) are separated from fulvic acids (FA) after centrifugation of the acidified extract $(p \mathrm{H} 2)$. The precipitate of humic acids is dissolved in sodium hydroxide and purified by dialysis and elution on an $\mathrm{H}+$ resin (Kononova and Bel'Chikova, 1960; Huc, 1973). Finally humic acids are freeze-dried. For further studies HA are hydrolyzed by refluxing for 16 hours in $6 \mathrm{~N} \mathrm{HCl}$.

Kerogens were obtained from 16 sediment samples after alkali treatment, according to a procedure described by Durand et al. (1972) and modified by Robin et al. (in press). The mineral fraction is dissolved through successive treatment at $70^{\circ} \mathrm{C}$, first with $4 N$ $\mathrm{HCl}$ then with a $1 / 3-2 / 3$ mixture of $4 N \mathrm{HCl}, \mathrm{HF} 40 \%$. The residue (KB) is washed with distilled water, and finally extracted by $\mathrm{CHCl}_{3}(\mathrm{KC})$. The loss of organic matter during the isolation of kerogen is determined from the difference between residual carbon and total carbon.

The analytical methods used here for humic acids, hydrolyzed humic acids and kerogens, are as follows: 


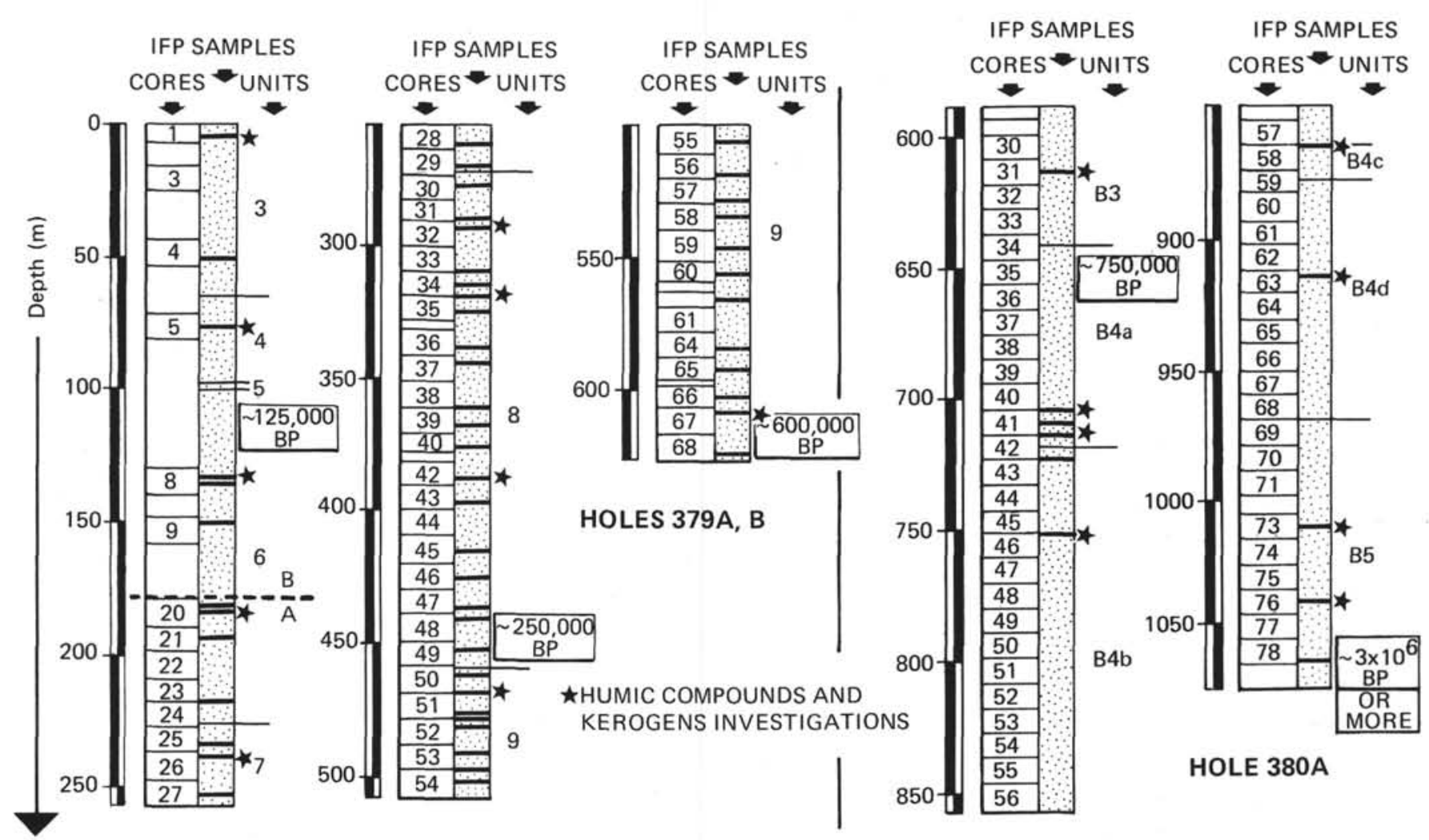

Figure 2. Lithologic units and sampling.

1) Determination of soluble organic carbon in aliquot portions from total humic compounds solutions and supernatant fulvic fractions is performed using a Carmograph Wosthoff apparatus.

2) Elemental analysis is performed by ATX (Suresnes, France), according to our indications. The $\mathrm{C}, \mathrm{H}, \mathrm{O}, \mathrm{N}, \mathrm{S}$ (+ $\mathrm{Fe}$ in the case of kerogens), and ash contents are measured on samples after drying at $80^{\circ} \mathrm{C}$ (HA) or $100^{\circ} \mathrm{C}$ (kerogens) in a vacuum. Calculations for corrected elemental analysis of kerogens on a mineral-free basis are made, assuming $\mathrm{Fe}$ to belong entirely to $\mathrm{FeS}_{2}$ minerals and the organic matter to be composed solely of $\mathrm{C}, \mathrm{H}, \mathrm{O}, \mathrm{N}$, and organic $\mathrm{S}$. Accordingly, organic $\mathrm{S}$ is calculated by taking the difference between total $\mathbf{S}$ and $\mathbf{S}$ from pyrite.

3) Infrared absorbance spectra with quantitative interpretation are recorded with a Beckman $42-40$ spectrometer. Kerogen or humic acids are dispersed in a $\mathrm{KBr}$ pellet, with a known concentration, pressed under $8000 \mathrm{~kg} / \mathrm{cm}_{2}$. In order to remove moisture, $\mathrm{KBr}$ pellets are stored 10 days in a dry atmosphere (Robin and Rouxhet, 1976). Absorbance of the different bands is determined by planimetry of the areas shown in Figure 8. The absorption coefficient $\mathrm{K}$ is obtained by relating the intensity to the effective concentration of organic material in $\mathrm{mg} / \mathrm{cm}_{2}$ (wave number $\times$ absorbance unit $\left.\times\left(\mathrm{mg} \times \mathrm{cm}_{2}\right)^{-1}\right)($ Robin et al., in press).

\section{RESULTS}

\section{Organic Carbon (100 samples)}

Organic carbon data are presented in Table 1 and Figure 4. Most values are low and cannot be correlated with stratigraphic units except with the "black varves" and "black shales" units where organic carbon contents are the highest.

\section{Mineral Carbon (100 samples)}

The values are presented in Table 1 and Figure 4 . We see no definite correlation between these data and the stratigraphic units.

\section{Hydrolyzable Organic Carbon (52 samples)}

The hydrolyzable fraction of the organic carbon falls in the $2 \%-43 \%$ range (Table 1 ). This fraction decreases as a function of the depth of burial, and in samples from Site 379 the rate of decrease is the highest during the firt 250 meters. In deep samples from Hole 380A the concentrations are low, i.e., 6\%-2\% (Figure 5).

\section{Distribution of Analytical Fractions in Organic Matter}

The organic substances soluble in $\mathrm{CHCl}_{3}$ amount to $1 \%-5 \%$ or the total organic substances in the sediments (21 samples), Figure 6. These values are practically the same as those found in soils and other sediments (Hunt, 1961). According to thin-layer chromatography (Huc et al., 1976), the polar compounds comprise about $70 \%$ $90 \%$ of the organic solvent-soluble substances.

Humic compounds extractable with alkalis range between $6.0 \%$ and $29.1 \%$ of the total organic substances (Table 2, Figure 6); in samples from Site 380, the concentrations are lower than those from Site 379 . Moreover the FA content appears to decrease progressively as a function of depth of burial and, except for Section 31-3, the FA/HA ratios are higher in shallow samples $(1-4 ; 5-3 ; 8-3 ; 28-5)$. 
TABLE 1

Data on Samples From Holes 379A, 379B, and 380A (organic carbon, hydrolyzable organic carbon as \% of the total organic carbon, mineral carbon)

\begin{tabular}{cccccc}
\hline Core Section & $\begin{array}{c}\text { Fragment } \\
\text { (IFP) }\end{array}$ & $\begin{array}{c}\text { Depth } \\
(\mathrm{m})\end{array}$ & $\begin{array}{c}\text { Org. C } \\
(\%)\end{array}$ & $\begin{array}{c}\text { Min. C } \\
(\%)\end{array}$ & $\begin{array}{c}\text { Hydr. C } \\
(\%)\end{array}$ \\
\hline
\end{tabular}

Hole 379B

$\begin{array}{rrrrrrr}1 & 4 & \text { a } & 4.5 & 0.41 & 2.88 & 43 . \\ & & \text { b } & & 0.42 & 2.98 & \\ & & \text { c } & & 0.46 & 2.62 & \\ & & \text { d } & & 0.45 & 2.78 & \\ 4 & 4 & \text { e } & & 0.48 & 2.76 & \\ 5 & 3 & & 49.7 & 0.17 & 1.62 & 41 . \\ 8 & 3 & & 77.8 & 0.59 & 1.48 & 20 . \\ & & \text { a } & 133.7 & 0.44 & 2.54 & \\ & & \text { b } & & 0.40 & 2.62 & \\ & & \text { c } & & 0.43 & 2.16 & \\ 8 & 3 & \text { d } & & 0.42 & 2.36 & \\ 9 & 1 & & 134.3 & 0.41 & 2.54 & \\ & & & 149.5 & 0.70 & 2.82 & 32.70 \\ \end{array}$

Hole 379A

\begin{tabular}{|c|c|c|c|c|c|c|}
\hline \multirow[t]{2}{*}{20} & 2 & a & 179.6 & 0.54 & 2.84 & \\
\hline & & b & & 0.54 & 2.64 & \\
\hline \multirow[t]{2}{*}{20} & 2 & c & 179.6 & 0.51 & 2.90 & \\
\hline & & d & & 0.49 & 2.90 & \\
\hline 20 & 2 & & 181.2 & 0.52 & 2.79 & 29. \\
\hline 21 & 3 & & 190.7 & 0.41 & 1.24 & 27. \\
\hline 23 & 7 & & 216.0 & 0.45 & 3.12 & 31. \\
\hline 25 & 4 & & 230.2 & 0.72 & 2.04 & 14. \\
\hline 26 & 1 & & 236.6 & 0.36 & 3.24 & 25. \\
\hline 27 & 4 & & 249.2 & 0.44 & 3.10 & 27. \\
\hline 28 & 5 & & 260.3 & 0.54 & 2.84 & 32. \\
\hline 29 & 4 & & 268.2 & 0.59 & 3.04 & 22. \\
\hline 30 & 3 & & 277.7 & 0.96 & 3.12 & 22. \\
\hline 31 & 6 & & 290.4 & 0.39 & 2.30 & 26. \\
\hline 32 & 2 & & 295.2 & 0.32 & 3.30 & 27. \\
\hline \multirow[t]{3}{*}{34} & 0 & a & 311.0 & 0.77 & 3.40 & \\
\hline & & b & & 0.75 & 2.82 & \\
\hline & & c & & 0.76 & 2.90 & \\
\hline 34 & 0 & d & 311.0 & 0.80 & 2.50 & \\
\hline \multirow[t]{5}{*}{34} & 3 & a & 314.2 & 0.59 & 2.90 & \\
\hline & & b & & 0.45 & 3.52 & \\
\hline & & c & & 0.63 & 3.74 & \\
\hline & & d & & 0.56 & 4.14 & \\
\hline & & e & & 0.61 & 3.14 & \\
\hline 34 & CC & & 320.5 & 0.50 & 3.92 & 26. \\
\hline 35 & 4 & & 327.6 & 0.28 & 2.70 & 29. \\
\hline 36 & 5 & & 336.3 & 0.65 & 3.02 & 20. \\
\hline 37 & 2 & & 342.7 & 0.37 & 3.42 & 31. \\
\hline 38 & 7 & & 358.5 & 0.32 & 2.84 & 22. \\
\hline 39 & 4 & & 364.8 & 0.38 & 2.26 & 28. \\
\hline 40 & 5 & & 374.3 & 0.25 & 3.28 & 28. \\
\hline 42 & 4 & & 382.2 & 0.58 & 3.44 & 20. \\
\hline \multirow[t]{6}{*}{43} & 4 & a & 393.3 & 0.25 & 2.98 & \\
\hline & & b & & 0.21 & 3.24 & \\
\hline & & c & & 0.25 & 3.20 & \\
\hline & & d & & 0.26 & 2.90 & \\
\hline & & e & & 0.24 & 3.12 & \\
\hline & & f & & 0.25 & 3.14 & \\
\hline 45 & 3 & & 409.2 & 0.33 & 3.24 & 22. \\
\hline 46 & 3 & & 418.7 & 0.26 & 3.06 & 21. \\
\hline 47 & 5 & & 432.9 & 0.43 & 3.16 & 20. \\
\hline 48 & 1 & & 434.5 & 0.48 & 2.32 & 15. \\
\hline 49 & 2 & & 445.6 & 0.28 & 2.92 & 24. \\
\hline 50 & 2 & & 455.1 & 0.33 & 2.60 & 28. \\
\hline 51 & 0 & & 463.0 & 0.30 & 2.84 & 25. \\
\hline 51 & 5 & & 470.9 & 0.35 & 2.22 & 26. \\
\hline 51 & $\mathrm{CC}$ & & 472.5 & 0.49 & 3.64 & 24. \\
\hline 52 & 2 & & 474.1 & 0.29 & 3.44 & 24. \\
\hline 53 & 2 & & 485.2 & 0.52 & 3.76 & 22. \\
\hline 54 & 0 & a & 491.5 & 0.43 & 3.84 & \\
\hline \multirow[t]{2}{*}{54} & 0 & b & & 0.43 & 3.84 & \\
\hline & & c & & 0.41 & 3.60 & \\
\hline
\end{tabular}

TABLE 1 - Continued

\begin{tabular}{cccccc}
\hline & Fragment & $\underset{(\mathrm{D})}{\text { Depth }}$ & $\underset{(\%)}{\text { Org. C }}$ & $\underset{(\%)}{\operatorname{Min} . \mathrm{C}}$ & $\underset{(\%)}{\text { Hydr. C }}$ \\
\hline
\end{tabular}

Hole 379A Continued

$\begin{array}{ll}54 & 3 \\ 55 & 3 \\ 56 & 6 \\ 57 & 6 \\ 58 & 3 \\ 59 & 4 \\ 60 & 5 \\ 62 & 3 \\ 64 & 4 \\ 65 & 3 \\ 66 & 3 \\ 67 & 1\end{array}$

$68 \quad 4$

d
f

$\begin{array}{llll} & 0.41 & 3.95 & \\ & 0.42 & 3.42 & \\ 496.2 & 0.51 & 4.00 & \\ 505.7 & 0.41 & 3.80 & 23 . \\ 520.0 & 0.30 & 3.12 & \\ 529.5 & 0.75 & 3.08 & \\ 532.7 & 0.29 & 4.82 & \\ 543.7 & 0.45 & 3.52 & 21 . \\ 554.8 & 0.33 & 3.46 & 15 . \\ 564.7 & 0.25 & 3.26 & 16 . \\ 583.3 & 0.34 & 2.80 & 25 . \\ 591.2 & 0.52 & 6.58 & 21 . \\ 599.2 & 0.41 & 3.80 & 25 . \\ 607.1 & 0.47 & 3.02 & 29 \\ & 0.33 & 2.16 & \\ & 0.18 & 1.88 & \\ 621.3 & 0.42 & 3.60 & \\ & 0.30 & 3.28 & 17 .\end{array}$

Hole 380A

\begin{tabular}{lcccccc}
31 & 3 & a & 612.7 & 0.77 & 1.28 & 21. \\
& & b & & 0.58 & 1.62 & \\
& & c & & 0.53 & 1.68 & \\
& & d & & 0.63 & 1.36 & \\
41 & 0 & e & & 0.59 & 0.67 & \\
41 & CC & & 703.0 & 2.20 & 0.37 & 11. \\
42 & 0 & & $712-5$ & 1.71 & 0.39 & 18. \\
42 & CC & & 722.0 & 1.32 & 0.30 & 19. \\
46 & 1 & & 750.5 & 2.26 & 1.54 & 1.10 \\
57 & CC & & 864.5 & 3.26 & 2.20 & 16. \\
63 & 1 & & 912 & 1.80 & 1.41 & 7 \\
73 & 4 & & 1013 & 1.70 & 1.62 & 6 \\
76 & 3 & & 1040.0 & 1.14 & 1.28 & 12. \\
78 & 6 & & 1063 & 2.20 & 1.17 & 12. \\
\hline
\end{tabular}

"Humin," or the organic substances remaining after alkali treatment, ranges between $70 \%$ and $94 \%$ of the total organic substances. The organic matter lost during kerogen isolation is close to that obtained by hydrolysis of the humin $(6 \mathrm{~N} \mathrm{HCl})($ Table 3$)$.

\section{Properties of Humic Acids-Elemental Composition}

The results of elemental analysis of humic acids from Sites 379 and 380 are given in Table 4. The data are plotted in a Van Krevelen diagram $(\mathrm{H} / \mathrm{C}$ versus $\mathrm{O} / \mathrm{C}$ ) together with data from humic acids from various known sources (Figure 7). Site 379 and Site 380 plots appear to be very scattered in this frame. This suggests diversity in the nature and origin of the humic acids in these sedimentary columns. However the properties of these compounds cannot be correlated with stratigraphic units. We can see that $\mathrm{O} / \mathrm{C}$ values are generally lower at Site 380 than at Site 379. The results of elemental analysis of hydrolyzed humic acids are given in Table 5. After hydrolysis $\mathrm{O} / \mathrm{C}$ ratios become very close to each other for all samples. $\mathrm{H} / \mathrm{C}$ ratios follow this trend to uniformization, but it remains a significative difference between samples.

\section{Properties of Humic Acids in Infrared Spectroscopy}

The absorption spectra of humic acids (Figure 8) show bands in the regions of: $2700-3400 \mathrm{~cm}^{-1}(\mathrm{H}$ bonded 


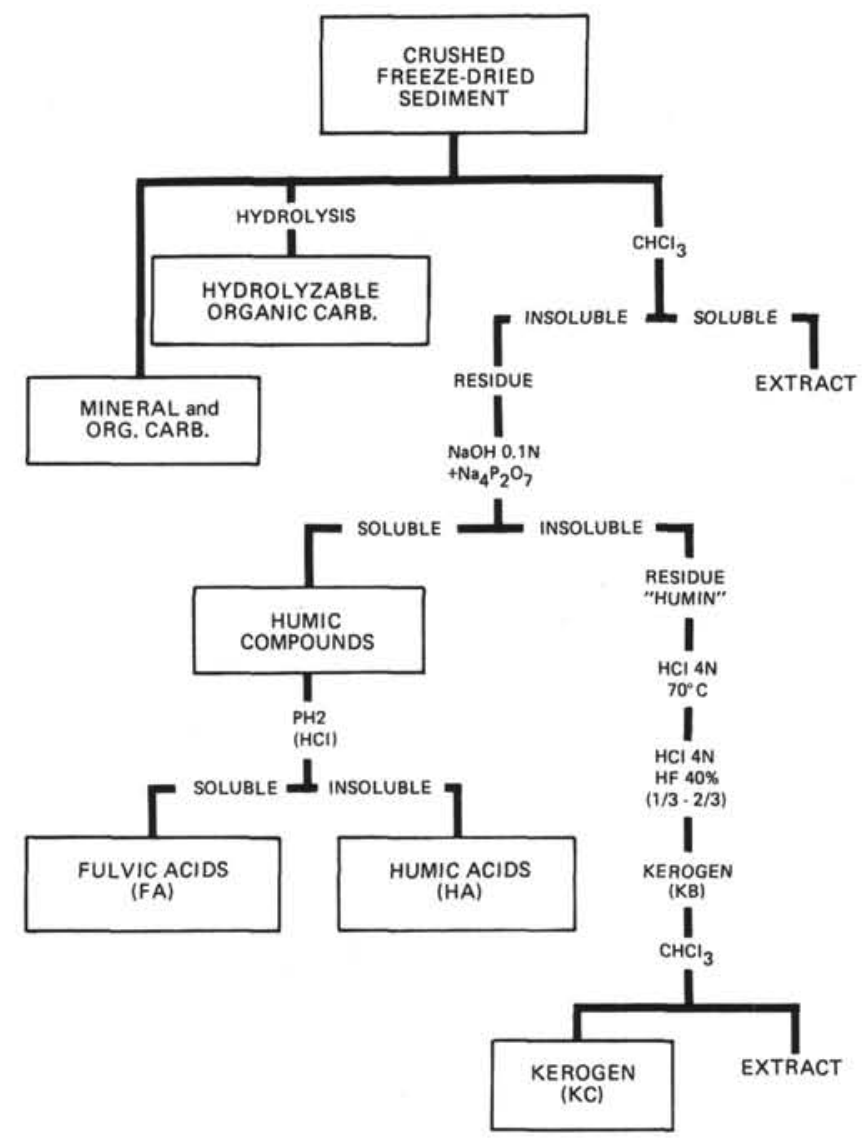

Figure 3. Flow diagram for analytical procedure.

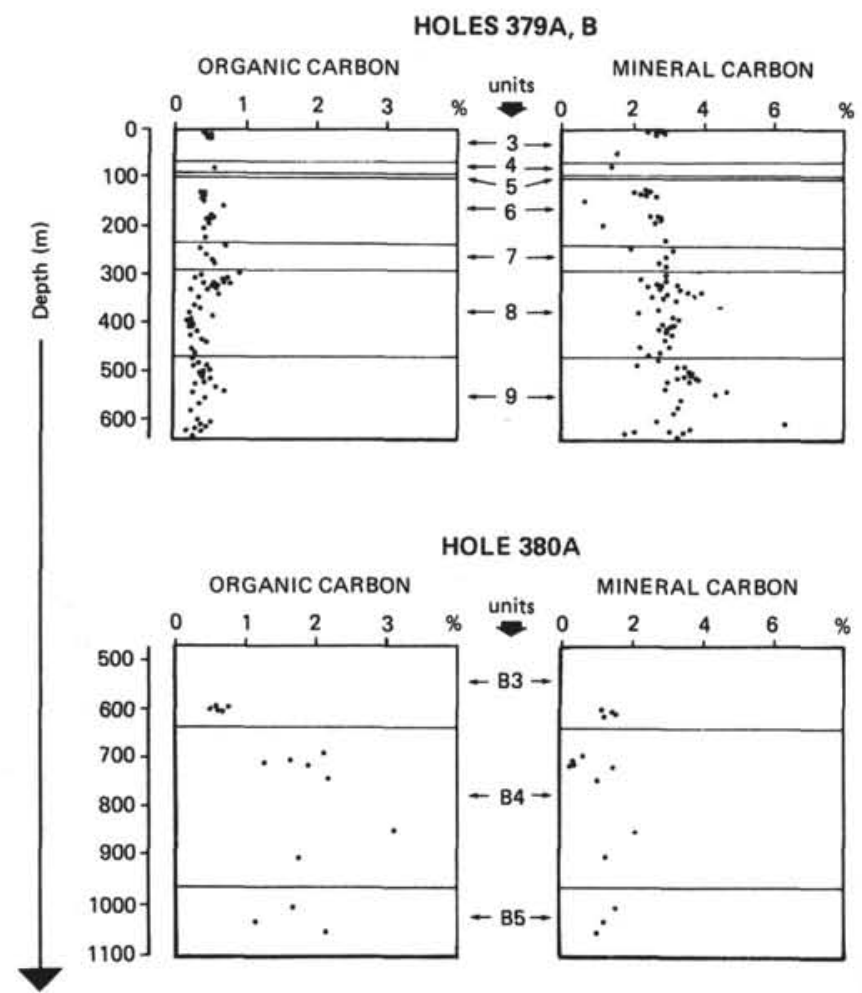

Figure 4. Organic and mineral carbon data.
HOLES 379A, B

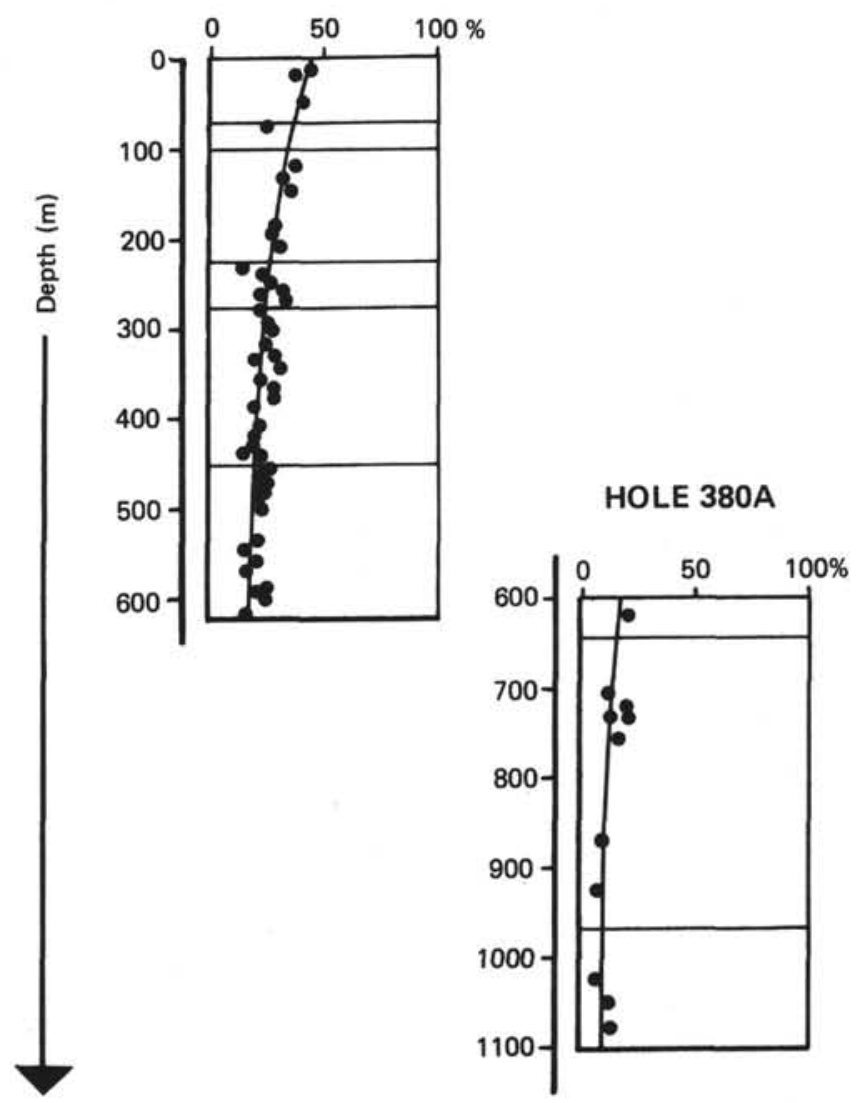

Figure 5. Variations in the hydrolyzable organic carbon fraction versus depth of burial.

HOLES 379A, B

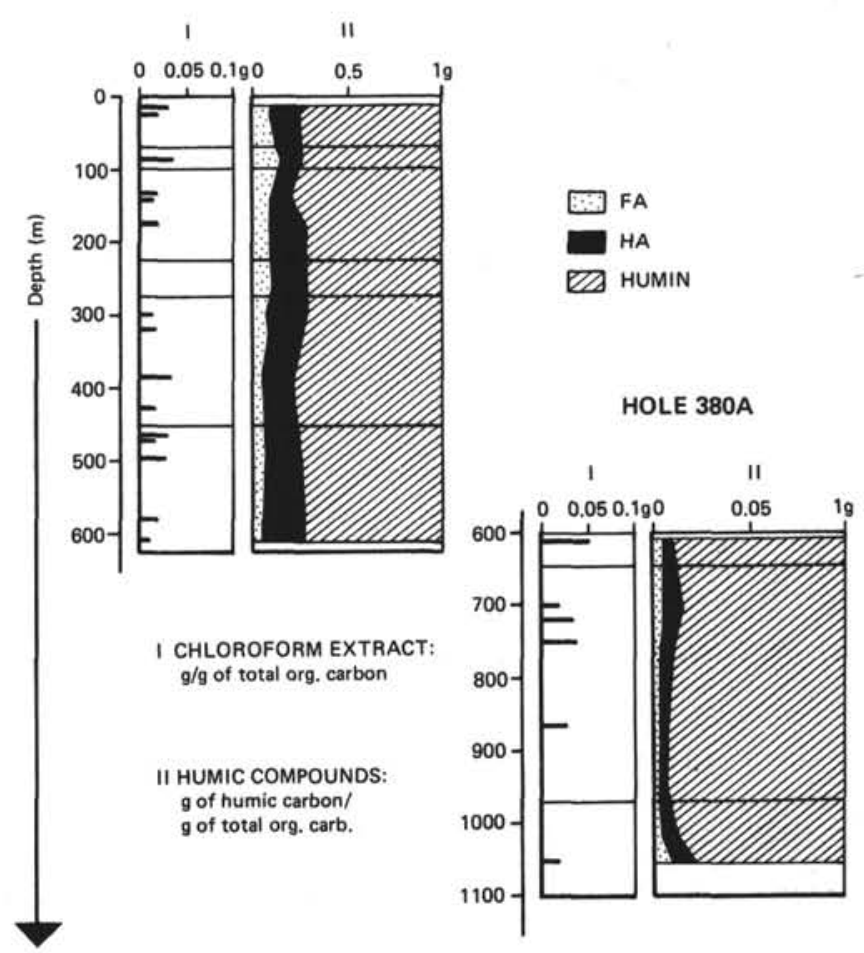

Figure 6. Distribution of analytical fractions in organic matter. 
TABLE 2

Humic Compound Contents ${ }^{\mathrm{a}}$

\begin{tabular}{|c|c|c|c|c|c|}
\hline $\begin{array}{l}\text { Core- } \\
\text { Section }\end{array}$ & $\begin{array}{c}\text { Total } \\
\text { Organic } \\
\text { Carbon }\end{array}$ & $\begin{array}{l}\text { Humic } \\
\text { Compound } \\
\text { (\% of total } \\
\text { Org. C) }\end{array}$ & $\mathrm{FA} / \mathrm{HA}$ & $\begin{array}{c}\text { FA } \\
\text { (\% of total } \\
\text { Org. C) }\end{array}$ & $\begin{array}{c}\text { HA } \\
\text { (\% of total } \\
\text { Org. C) }\end{array}$ \\
\hline \multicolumn{6}{|c|}{ Hole 379B } \\
\hline $1-4$ & 0.41 & 28.6 & 0.60 & 10.7 & 17.9 \\
\hline $1-4$ & 0.46 & 24.0 & 0.67 & 9.6 & 14.4 \\
\hline $5-3$ & 0.59 & 25.4 & 1.38 & 14.7 & 10.7 \\
\hline $8-3$ & 0.44 & 19.7 & 1.03 & 10.0 & 9.7 \\
\hline \multicolumn{6}{|c|}{ Hole 379A } \\
\hline $20-2$ & 0.54 & 28.0 & 0.47 & 9.0 & 19.0 \\
\hline 28.5 & 0.54 & 29.6 & 0.62 & 11.3 & 18.3 \\
\hline $32-2$ & 0.32 & 29.1 & 0.38 & 7.9 & 21.2 \\
\hline 34-CC & 0.50 & 26.1 & 0.45 & 8.2 & 17.9 \\
\hline $42-4$ & 0.58 & 21.0 & 0.35 & 4.9 & 16.1 \\
\hline $51-0$ & 0.30 & 23.5 & 0.48 & 7.7 & 15.8 \\
\hline $67-1$ & 0.47 & 28.6 & 0.27 & 6.0 & 22.6 \\
\hline \multicolumn{6}{|c|}{ Hole $380 \mathrm{~A}$} \\
\hline $31-3$ & 0.77 & 7.8 & 1.16 & 4.2 & 3.6 \\
\hline $41-0$ & 2.20 & 13.4 & 0.39 & 3.7 & 9.7 \\
\hline $41-3$ & 1.71 & 11.7 & 0.35 & 3.1 & 8.6 \\
\hline $46-1$ & 2.26 & 9.8 & 0.37 & 2.6 & 7.2 \\
\hline $57-\mathrm{CC}$ & 3.26 & 6.0 & 0.46 & 1.9 & 4.1 \\
\hline $63-1$ & 1.80 & 4.7 & 0.51 & 1.6 & 3.1 \\
\hline $73-4$ & 1.70 & 10.4 & 0.18 & 1.6 & 8.8 \\
\hline $76-3$ & 1.14 & 19.6 & 0.44 & 5.9 & 13.7 \\
\hline
\end{tabular}

${ }^{\mathrm{a}} \mathrm{FA}=$ fulvic acids carbon; $\mathrm{HA}=$ humic acids carbon.

TABLE 3

Hydrolyzable Proportion of Humic Acids and Humins

\begin{tabular}{|c|c|c|c|c|}
\hline $\begin{array}{l}\text { Core- } \\
\text { Section }\end{array}$ & $\begin{array}{c}\text { Total } \\
\text { Hydrolyzable } \\
\text { Organic } \\
\text { Carbon (\%) }\end{array}$ & $\begin{array}{l}\text { Hydrolyzable } \\
\text { Humic } \\
\text { Carbon (\%) }\end{array}$ & $\begin{array}{l}\text { Hydrolyzable } \\
\text { Humin } \\
\text { Carbon (\%) }\end{array}$ & $\begin{array}{c}\text { Loss of } \\
\text { Organic Carbon } \\
\text { During Kerogen } \\
\text { Isolation (\%) }\end{array}$ \\
\hline
\end{tabular}

Hole 379B

$\begin{array}{lllll}1-4 & 43 & 13 & 36 & 37 \\ 1-4 & 39 & 16 & 36 & 36 \\ 5-3 & 24 & 12 & 23 & 31 \\ 8-3 & 37 & - & - & 35\end{array}$

Hole 379A

$\begin{array}{llrll}20-2 & 28 & 5 & 30 & 32 \\ 32-2 & 27 & 10 & 28 & 35 \\ 34, C C & 26 & 8 & 25 & 31 \\ 42-4 & 20 & 9 & 23 & 28 \\ 51-0 & 25 & 2 & 27 & 39 \\ 67-1 & 29 & 3 & 28 & 27\end{array}$

Hole 380A

\begin{tabular}{lllll}
$31-3$ & 21 & 0 & 18 & 13 \\
$41-0$ & 11 & - & - & 17 \\
$41-3$ & 18 & 0 & 21 & 24 \\
$46-1$ & 16 & 0 & 13 & 13 \\
$57, \mathrm{CC}$ & 10 & 2 & 13 & 1 \\
$76-3$ & 12 & 0 & 14 & 11 \\
\hline
\end{tabular}

$\mathrm{OH}$ ) including two broads bands: around $3200 \mathrm{~cm}$ and $2600 \mathrm{~cm}^{-1}$ (acidic OH); $2920 \mathrm{~cm}^{-1}$ (aliphatic C-H stretching from $\mathrm{CH}_{2}$ and $\left.\mathrm{CH}_{3}\right) ; 1720 \mathrm{~cm}^{-1}(\mathrm{C}=\mathrm{O}$ stretching from $\mathrm{COOH}, \mathrm{COOR}$ and ketonic $\mathrm{C}=\mathrm{O}$ ); $1630 \mathrm{~cm}^{-1}$ (aromatic $\mathrm{C}=\mathrm{C}$; olefinic $\mathrm{C}=\mathrm{C}$; quinonic $\mathrm{C}$ $=0) ; 1455 \mathrm{~cm}^{-1}\left(\mathrm{CH}\right.$ deformation from $\mathrm{CH}_{2}$ and $\left.\mathrm{CH}_{3}\right)$; $1375 \mathrm{~cm}^{-1}$ ( $\mathrm{CH}$ deformation from $\mathrm{CH}_{3}$ ); $1040 \mathrm{~cm}^{-1}$ (C$\mathrm{O}$ of polysaccharide-like substances); however $\mathrm{SiO}$ may
TABLE 4

Elemental Analysis of Humic Acids

\begin{tabular}{|c|c|c|c|c|c|c|c|c|}
\hline \multirow[b]{2}{*}{$\begin{array}{l}\text { Core- } \\
\text { Section }\end{array}$} & \multicolumn{5}{|c|}{ Elemental Analysis } & \multicolumn{3}{|c|}{ Atomic Ratios } \\
\hline & $\mathrm{C}$ & $\mathrm{H}$ & $\mathrm{O}$ & $\mathrm{N}$ & $\mathrm{S}$ & $\mathrm{H} / \mathrm{C}$ & $\begin{array}{c}\mathrm{O} / \mathrm{C} \\
\times 10^{2}\end{array}$ & $\begin{array}{l}\mathrm{N} / \mathrm{C} \\
\times 10^{2}\end{array}$ \\
\hline
\end{tabular}

Hole 379B

$\begin{array}{lllllllll}1-4 & 56.87 & 5.08 & 32.13 & 3.86 & 2.05 & 1.07 & 42.37 & 5.82 \\ 1-4 & 57.40 & 5.28 & 31.29 & 3.99 & 2.04 & 1.10 & 40.89 & 5.96 \\ 5-3 & 54.00 & 5.22 & 31.78 & 3.42 & 5.58 & 1.16 & 44.13 & 5.42 \\ 8-4 & 56.89 & 5.05 & 32.34 & 3.74 & 1.98 & 1.06 & 42.63 & 5.64\end{array}$

Hole 379A

$\begin{array}{lllllllll}20-2 & 56.46 & 4.00 & 33.98 & 3.25 & 2.30 & 0.85 & 45.14 & 4.94 \\ 28-5 & 56.39 & 5.42 & 31.68 & 5.26 & 1.25 & 1.15 & 42.13 & 8.00 \\ 32-2 & 53.94 & 4.43 & 33.97 & 3.11 & 4.55 & 0.99 & 47.23 & 4.94 \\ 34-\mathrm{CC} & 55.66 & 4.89 & 33.00 & 3.56 & 2.90 & 1.05 & 44.47 & 5.48 \\ 42-4 & 56.39 & 5.53 & 32.10 & 3.32 & 2.66 & 1.18 & 42.70 & 5.04 \\ 51-0 & 54.83 & 4.36 & 34.84 & 3.51 & 2.46 & 0.95 & 47.66 & 5.48 \\ 67-1 & 60.50 & 5.51 & 28.49 & 3.00 & 2.50 & 1.09 & 35.31 & 4.25\end{array}$

Hole 380A

$\begin{array}{lllllllll}31-3 & 57.92 & 4.40 & 32.05 & 3.25 & 2.38 & 0.91 & 41.50 & 4.81 \\ 41-0 & 61.23 & 4.76 & 28.23 & 4.09 & 1.68 & 0.93 & 34.58 & 5.72 \\ 41-3 & 60.56 & 4.75 & 28.95 & 3.77 & 1.96 & 0.94 & 35.85 & 5.34 \\ 46-1 & 61.85 & 5.70 & 26.69 & 3.98 & 1.78 & 1.11 & 32.37 & 5.52 \\ 57-C C & 62.32 & 6.46 & 24.45 & 3.33 & 3.44 & 1.24 & 29.42 & 4.58 \\ 63-1 & 62.04 & 5.35 & 26.73 & 2.51 & 3.38 & 1.03 & 32.31 & 3.47 \\ 73-4 & 59.82 & 5.16 & 28.40 & 3.08 & 3.55 & 1.03 & 35.60 & 4.48 \\ 76-3 & 61.58 & 5.02 & 27.48 & 2.75 & 3.17 & 0.98 & 33.47 & 3.83\end{array}$

be responsible for absorption near $1000 \mathrm{~cm}^{-1}$ and accordingly the assignment to carbohydrates must be assumed with care in humic acids with high ash content. This band disappears in hydrolysis residues (Figure 12) when it is really related to carbohydrates.

The spectra of the near sea-bottom humic acids show additional absorption bands due to peptide linkages, i.e., $1650 \mathrm{~cm}^{-1}$ (amide $\mathrm{C}=\mathrm{O}$ ) which may shift the maximum of the $1630 \mathrm{~cm}$ band, and $1540 \mathrm{~cm}^{-1}$ (amide $\mathrm{NH}+\mathrm{CN}$ ) (Bellamy, 1958; Stevenson and Goth, 1971; Ishiwatari, 1967; Robin et al., in press).

Infrared spectra of humic acids from Sites 379 and 380 are shown in Figures 9 and 10. For comparative purposes, quantitative data on the absorption bands are given in Table 6, including K3400, K2920, K1720, $\mathrm{K} 1630$, K1540, and $\mathrm{K} 1375 / \mathrm{K} 1455$. The ratio K1375/K1455 provides an estimate of the ratio $\mathrm{CH}_{3} / \mathrm{CH}_{2}+\mathrm{CH}_{3}$. There is a reverse relationship between this ratio and the intensity values of $\mathrm{K} 2920$ of $\mathrm{CH}$ groups given by K2920 (Figure 14). The infrared spectra show great variety in their main features, especially in the saturated $\mathrm{C}-\mathrm{H}$ values (Table 6), which is in good agreement with the $\mathrm{H} / \mathrm{C}$ ratio values (Figure 11).

We can also observe the occurrence of the absorption bands assigned to peptide linkages $\left(1650 \mathrm{~cm}^{-1}\right.$ and 1540 $\mathrm{cm}^{-1}$ ) in humic acids associated with shallow samples (1-4 [a], 1-4 [c], 5-3) and their disappearance as a function of depth (Table 6).

\section{Properties of Kerogens}

Nineteen kerogens were isolated, but only 11 were analyzed because of the high ash content ( $>40 \%)$ of the other eight. The loss of organic matter during the isolation of kerogen or during $6 \mathrm{~N} \mathrm{HCl}$ hydrolysis of the humin is higher than the loss of organic matter during $6 N \mathrm{HCl}$ hydrolysis of the humic acids (Table 3). 


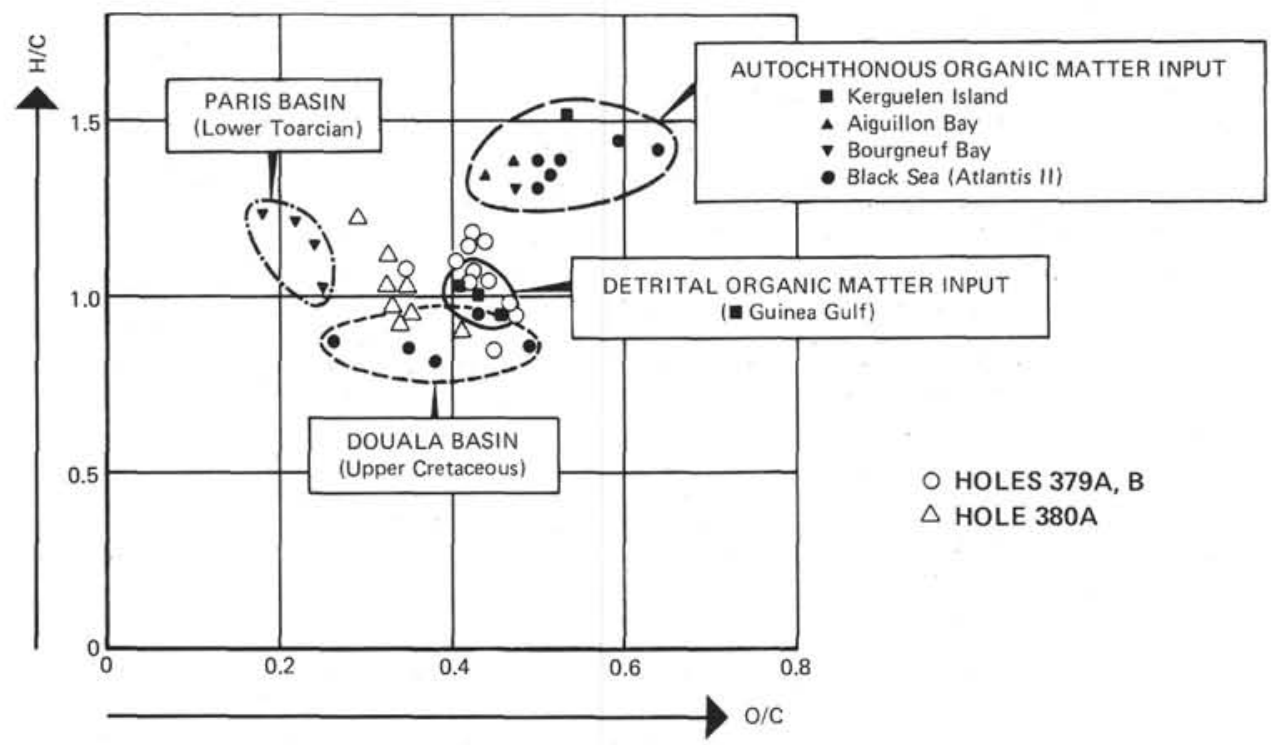

Figure 7. H/C versus O/C diagram - humic acids from Sites 379 and 380 compared with humic acids from various origins.

TABLE 5

Elemental Analysis of Hydrolyzed Humic Acids

\begin{tabular}{|c|c|c|c|c|c|c|c|c|}
\hline \multirow[b]{2}{*}{$\begin{array}{c}\text { Core- } \\
\text { Section }\end{array}$} & \multirow[b]{2}{*}{ C } & \multicolumn{2}{|c|}{ Elemental } & \multirow[b]{2}{*}{$\mathrm{N}$} & \multirow[b]{2}{*}{$\mathrm{S}$} & \multicolumn{3}{|c|}{ Atomic Ratios } \\
\hline & & H & 0 & & & $\mathrm{H} / \mathrm{C}$ & $\begin{array}{c}\mathrm{O} / \mathrm{C} \\
\times 10^{2}\end{array}$ & $\begin{array}{l}\mathrm{N} / \mathrm{C} \\
\times 10^{2}\end{array}$ \\
\hline \multicolumn{9}{|c|}{ Hole 379B } \\
\hline 14 & 63.74 & 4.84 & 26.96 & 2.91 & 1.56 & 0.91 & 31.72 & 3.91 \\
\hline $1-4$ & 63.55 & 5.08 & 25.84 & 2.77 & 2.76 & 0.96 & 30.50 & 3.74 \\
\hline $5-3$ & 62.99 & 5.06 & 25.06 & 2.39 & 4.50 & 0.96 & 29.84 & 3.26 \\
\hline
\end{tabular}

Hole 379A

$\begin{array}{lllllllll}20-2 & 57.71 & 3.67 & 31.39 & 2.64 & 4.60 & 0.76 & 40.79 & 3.92 \\ 32-2 & 60.05 & 4.33 & 29.24 & 2.67 & 3.71 & 0.87 & 36.53 & 3.81 \\ 34, \text { CC } & 63.08 & 4.73 & 25.75 & 3.05 & 3.33 & 0.91 & 30.62 & 4.15 \\ 42-4 & 65.20 & 5.19 & 23.58 & 3.03 & 3.00 & 0.96 & 27.13 & 3.98 \\ 51-0 & 58.92 & 4.19 & 30.09 & 2.82 & 3.98 & 0.85 & 38.30 & 4.10 \\ 67-1 & 62.70 & 5.40 & 25.33 & 2.94 & 3.63 & 1.03 & 30.30 & 4.02\end{array}$

Hole 380A

\begin{tabular}{lllllllll}
$31-3$ & 60.97 & 4.02 & 30.00 & 2.80 & 2.22 & 0.79 & 36.91 & 3.93 \\
$41-3$ & 62.25 & 4.63 & 25.29 & 3.36 & 4.47 & 0.89 & 30.47 & 4.63 \\
$46-1$ & 64.02 & 5.28 & 24.04 & 3.98 & 2.68 & 0.99 & 28.17 & 5.33 \\
57, CC & 65.88 & 6.06 & 21.03 & 2.91 & 4.12 & 1.10 & 23.95 & 3.79 \\
$76-3$ & 62.04 & 4.73 & 24.02 & 2.19 & 7.01 & 0.92 & 29.04 & 3.02 \\
\hline
\end{tabular}

Data on elemental composition of kerogens are recorded in Table 7 and plotted in a $\mathrm{H} / \mathrm{C}$ versus $\mathrm{O} / \mathrm{C}$ diagram (Figure 12).

In many cases, by reason of an important amount of ashes, the infrared spectra of kerogens with high ash contents are unreliable. However when elemental analysis shows a low ash content infrared spectra were successfully recorded. In these cases, by comparison with humic acids and hydrolyzed humic acids the following observations were made (Figure 13):

1) The peaks around $2900 \mathrm{~cm}^{-1}$ are similar in humic acids, hydrolysis residue, and kerogen.

2) The peaks at $1720 \mathrm{~cm}^{-1}$ and $1630 \mathrm{~cm}^{-1}$ are always smaller in kerogen.

3) The region $1200-1300 \mathrm{~cm}^{-1}$, assigned to several $\mathrm{C}-\mathrm{O}$ - bands (acids, phenols, aromatic ethers) is always smaller in kerogen.

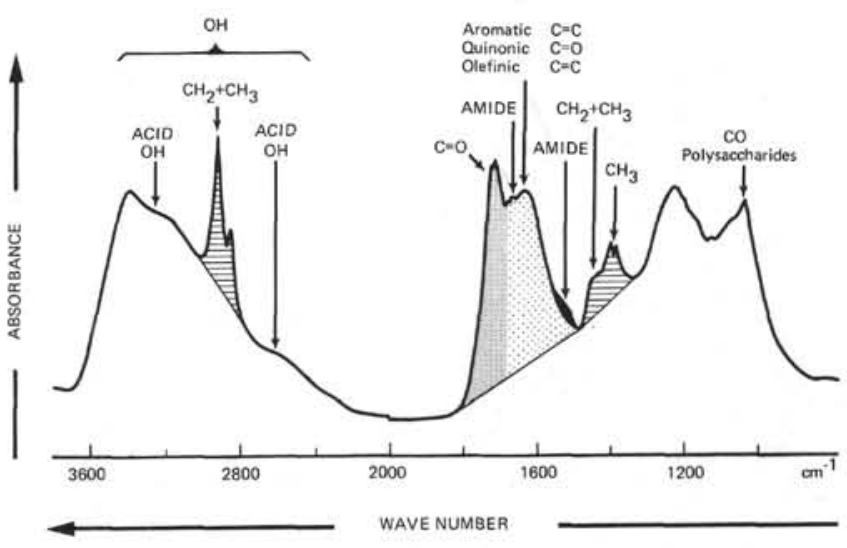

Figure 8. Infrared spectrum of sedimentary humic acids, assignment of bands.

4) The region $1370-1460 \mathrm{~cm}^{-1}$, shows an interesting difference: in kerogen the band around $1455 \mathrm{~cm}^{-1}$ is relatively higher than the band around $1375 \mathrm{~cm}^{-1}$. Hence the ratio $\mathrm{CH}_{3} / \mathrm{CH}_{2}+\mathrm{CH}_{3}$ tentatively provided by the ratio K1375/K1455, which is shown in Figure 14 , is higher in humic acids and hydrolysis residue than in related kerogen.

\section{DISCUSSION}

\section{Nature of Organic Matter}

Previous research has pointed out that in recent and ancient sediments the properties of humic acids were related to the nature of parent organic matter (Huc et al., 1974; Huc and Durand, 1977). In a general way two extreme types can be distinguished. Parent organic matter derived largely from land-plant, has high humic acid extratibility, and the humic acids are hydrogen poor, which is related to a low $\mathrm{H} / \mathrm{C}$ ratio and a low intensity of $\mathrm{CH}$ groups in infrared spectra. So are the humic acids which are isolated from sediments taken from the Gulf of Guinea (Huc and Durand, 


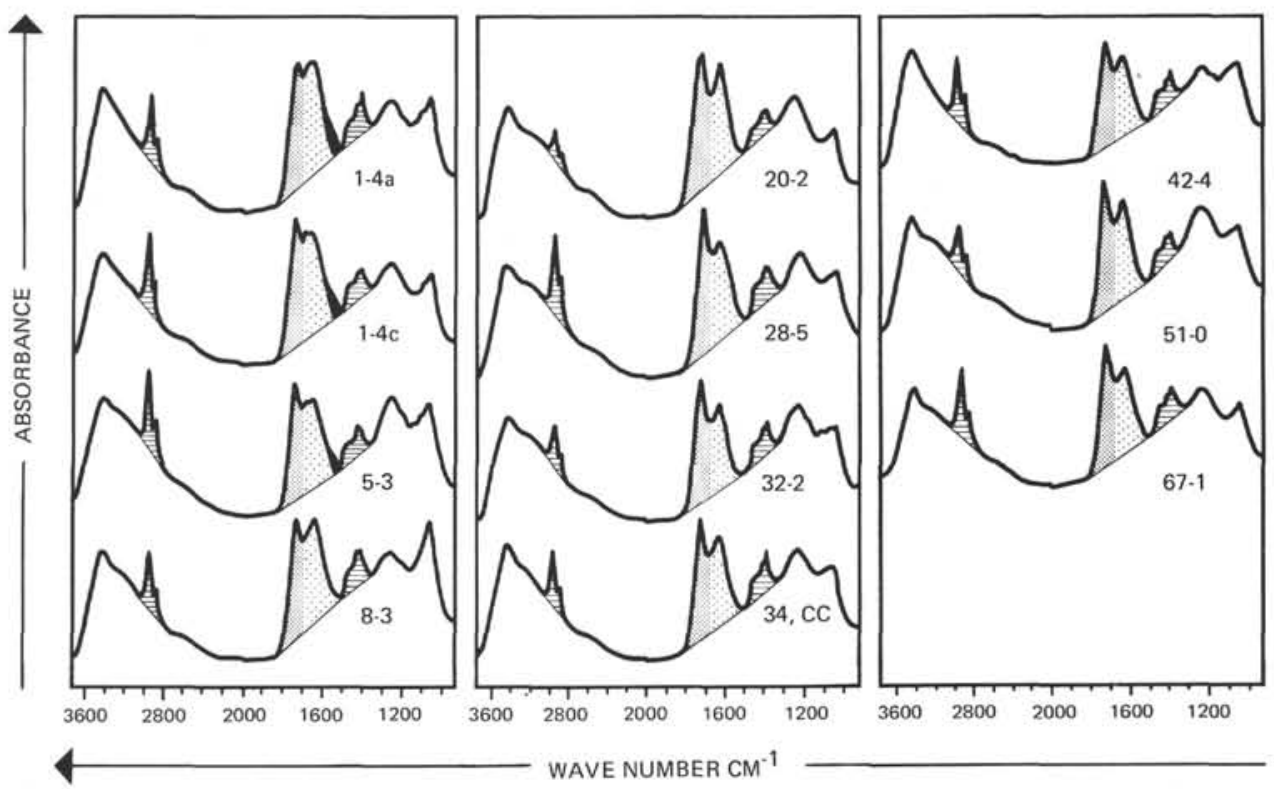

Figure 9. Infrared spectra of humic acids from Site 379.

1973), deposited in a deltaic environment (Klingebiel et al., 1975), and from an Upper Cretaceous series from the Douala Basin (Huc and Durand, 1977) deposited in a detrital environment (Dunoyer de Segonzac, 1969).

On the other hand, organic matter which is devoid of products derived from land plants has lower humic acids extractibility, and the humic acids are hydrogen rich, which is related to high $\mathrm{H} / \mathrm{C}$ ratio and high absorbance of $\mathrm{CH}$ groups in infrared spectra. This occurs in humic acids from Aiguillon Bay (Huc, 1973), Bourgneuf Bay (Debyser et al., 1975), young Black Sea sediments (Debyser and Pelet, in preparation), Kerguelen Island, and Toarcian shales from the Paris Basin (Tissot et al., 1971; Huc and Durand, 1977). In these cases the parent organic material is mainly marine organism, i.e., diatoms are the main organic source in Aiguillon Bay and Bourgeuf Bay (Gouleau, 1975). Algae have been recognized to amount to as much as two-thirds of the sedimentary organic material in the Black Sea Basin (Shimkus and Trimonis, 1974). Bethic algae are the sole source in the Kerguelen Island sample (Debyser et al., 1977). (Figure 15).

Thus $\mathrm{H} / \mathrm{C}$ ratio and intensity of $\mathrm{C}-\mathrm{H}$ bands from infrared spectra of humic acids can be used in this respect to make some distinctions between their parent organic matter. These parameters reveal variations in the nature of the organic matter input during the course of sedimentation (Figure 11). We deduce from low values of $\mathrm{H} / \mathrm{C}$ and of intensity of $\mathrm{CH}$ infrared bands that the organic matter input is more allochthonous; higher values are related to more autochthonous organic matter input. However, we must keep in mind that the balance of the allochthonous-autochtonous contribution to the humic acids obviously does not correlate with the stratigraphic units as previously described in the shipboard report.

\section{Transformation of Organic Matter With Depth}

We can follow the transformation of sedimentary organic matter during approximately $3 \times 10^{6}$ years: 0 -
600,000 B.P. at Site 379 and $750,000-3 \times 10^{6}$ years B.P. at Site 380 (according to data from the shipboard report). (Ed. comment: base of Site 380 may be upper Miocene or about $5 \times 10^{6}$ B.P.)

The decrease in the hydrolyzable fraction of total organic matter, humic acids and humins occurs as a function of depth of burial within the cores studied. These observations agree to some extent with the results noted in short cores by Bordovskiy (1965) in Bering Sea sediments and by Huc and Durand (1973) in Gulf of Guinea sediments. In Site 379 and 380 sediments, this trend is observed for the first time over a large depth range $(0-1000 \mathrm{~m})$. This indicates that structural changes occur at depth in the organic matter, leading it towards a resistant status.

We can see a decrease in the FA content and in FA/HA ratio between near sea-bottom samples and the deeper ones. In the case of soils, these values decrease with the increasing degree of humification. Moreover, the obvious decrease in the humiccompounds content from Site 379 to the older Site 380 might be connected to changes in the organic matter losing hydrophilic groups, hence its extractability by diluted alkali solutions.

The rapid decrease and disappearance of proteinaceous-like material associated with humic acids, as inferred from the decrease in IR absorption bands at $1650 \mathrm{~cm}^{-1}$ and $1540 \mathrm{~cm}^{-1}$, agrees with the observations made by Ishiwatari (1972) on humic acids from Japanese lakes and from Sea of Japan and by Huc and Durand (1973) on humic acids from the Gulf of Guinea.

From the Van Krevelen diagram it appears that the $\mathrm{O} / \mathrm{C}$ ratio in humic acids is, as a mean, lower in deeper samples from Sites 379 and 380. This result was expected from the comparison between humic acids of ancient and recent sediments (Figure 7) (Huc and Durand, 1977). The samples from Leg 42B fill the gap between recently deposited and ancient organic matter (commonly sampled in petroleum prospects). Moreover it is interesting to see that as the $\mathrm{H} / \mathrm{C}$ ratio 


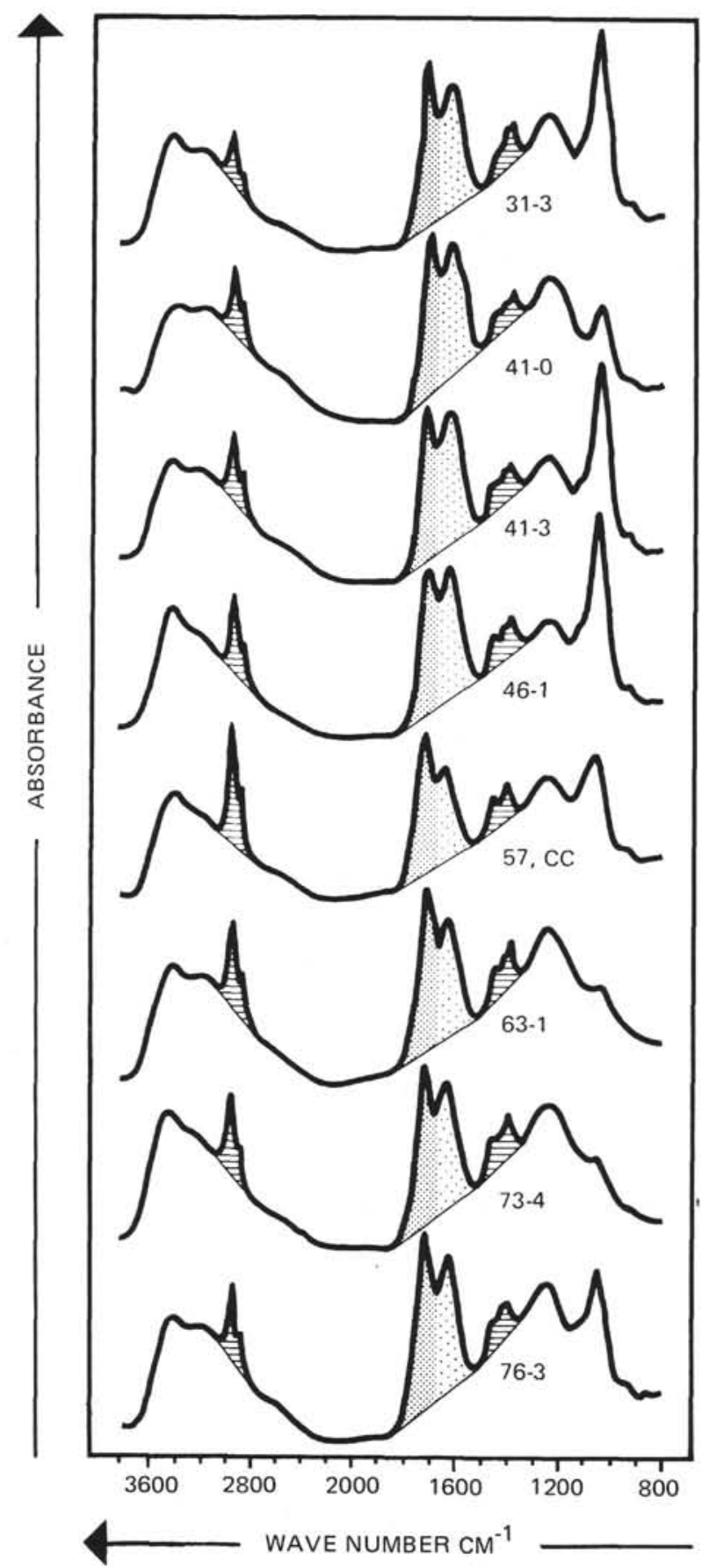

Figure 10. Infrared spectra of humic acids from Site 380.

is high, the $\mathrm{O} / \mathrm{C}$ ration decreases more easily. This might mean that at these stages of evolution in the $\mathrm{O} / \mathrm{C}$ decrease is more important in autochthonous organic matter than in land-derived organic matter. We are inclined to consider that, in humic acids from autochthonous material, the oxygen might be included in the molecule as a labile form, with respect to their evolution in this early diagenesis. In landderived humic acids, oxygen is more firmly incorporated in the structure.

\section{Formation of Kerogen}

The kerogen in a sedimentary rock can be analytically defined as the insoluble organic matter
TABLE 6

Infrared Absorption Measurements K3400, $\mathrm{K} 2920, \mathrm{~K} 1720, \mathrm{~K} 1630, \mathrm{~K} 1540$, and K1375/K1455 of Humic Acids (infrared units)

\begin{tabular}{lccccc}
\hline $\begin{array}{c}\text { Core- } \\
\text { Section }\end{array}$ & K2920 & K1720 & K1630 & K1540 & $\begin{array}{c}\text { K1375/ } \\
\text { K1455 }\end{array}$ \\
\hline Hole 379B & & & & & \\
& & & & & \\
$1-4$ & 20.4 & 46.1 & 50.5 & 3.1 & 2.10 \\
$1-4$ & 28.4 & 53.1 & 49.2 & 2.4 & 1.47 \\
$5-3$ & 26.6 & 45.1 & 39.9 & 1.4 & 1.67 \\
$8-3$ & 23.5 & 50.1 & 52.6 & - & 1.65
\end{tabular}

Hole 379A

$\begin{array}{llllll}20-2 & 11.7 & 53.1 & 51.6 & - & 2.95 \\ 28-5 & 32.4 & 57.0 & 46.6 & - & 1.83 \\ 32-2 & 16.6 & 49.8 & 44.5 & - & 1.92 \\ 34, \text { CC } & 22.4 & 50.1 & 45.9 & - & 2.58 \\ 42-4 & 28.6 & 44.5 & 41.4 & - & 1.84 \\ 51-0 & 17.7 & 52.5 & 47.3 & - & 1.68 \\ 67-1 & 29.1 & 49.6 & 39.2 & - & 1.69\end{array}$

Hole $380 \mathrm{~A}$

\begin{tabular}{llllll}
$31-3$ & 17.4 & 53.9 & 46.5 & - & 2.50 \\
$41-0$ & 23.9 & 52.9 & 51.0 & - & 1.30 \\
$41-3$ & 25.0 & 47.5 & 52.6 & - & 1.84 \\
$46-1$ & 28.5 & 45.5 & 49.0 & - & 1.75 \\
$57, \mathrm{CC}$ & 36.9 & 41.5 & 31.8 & - & 0.98 \\
$63-1$ & 30.0 & 53.7 & 39.1 & - & 1.38 \\
$73-4$ & 25.3 & 49.1 & 46.3 & - & 1.18 \\
$76-3$ & 23.1 & 53.6 & 45.7 & - & 1.02 \\
\hline
\end{tabular}

Note: Absorption measurement $\mathrm{K}$ is obtained by relating the intensity (planimetered absorbance peak areas) to the effective concentration of organic material in $\mathrm{mg} / \mathrm{cm}^{2}$ : [(wave number $\mathrm{X}$ absorbance unit $\mathrm{X}(\mathrm{mg} \mathrm{X}$ $\left.\left.\left(\mathrm{cm}^{2}\right)^{-1}\right)\right]$.

remaining after destruction of the mineral material by hydrochloric and hydrofluoric acids. In ancient sediment this procedure ineffectively degrades organic matter, and the resulting kerogen is representative of the insoluble part of the organic matter. On the other hand, in young deposits, the insoluble organic matter, called humin, is easily hydrolyzable and the remaining kerogen represents only a fraction of it. Hence, natural evolution leads from a kerogen poorly representative of the bulk of the insoluble organic matter towards a representative kerogen. This might explain the different kerogen locations (between Site 379 and Site 380) in a Van Krevelen Diagram (Figure 13). It would be worthwhile to study the hydrolyzable fraction of the organic matter. This investigation is not easy with present analytical procedures. However, this fraction is of interest because of its behavior, i.e., it seems to be incorporated into kerogen through natural evolution.

\section{CONCLUSION}

In spite of a possible contribution of evolved detrital organic matter by detrital input that may cause scattering in the results, this study reveals some interesting trends as follows:

1) The differences in humic acids properties in the sedimentary column suggest that organic matter inputs and prevailing sedimentary environments have been changing during the last 3 million or 5 million years in 

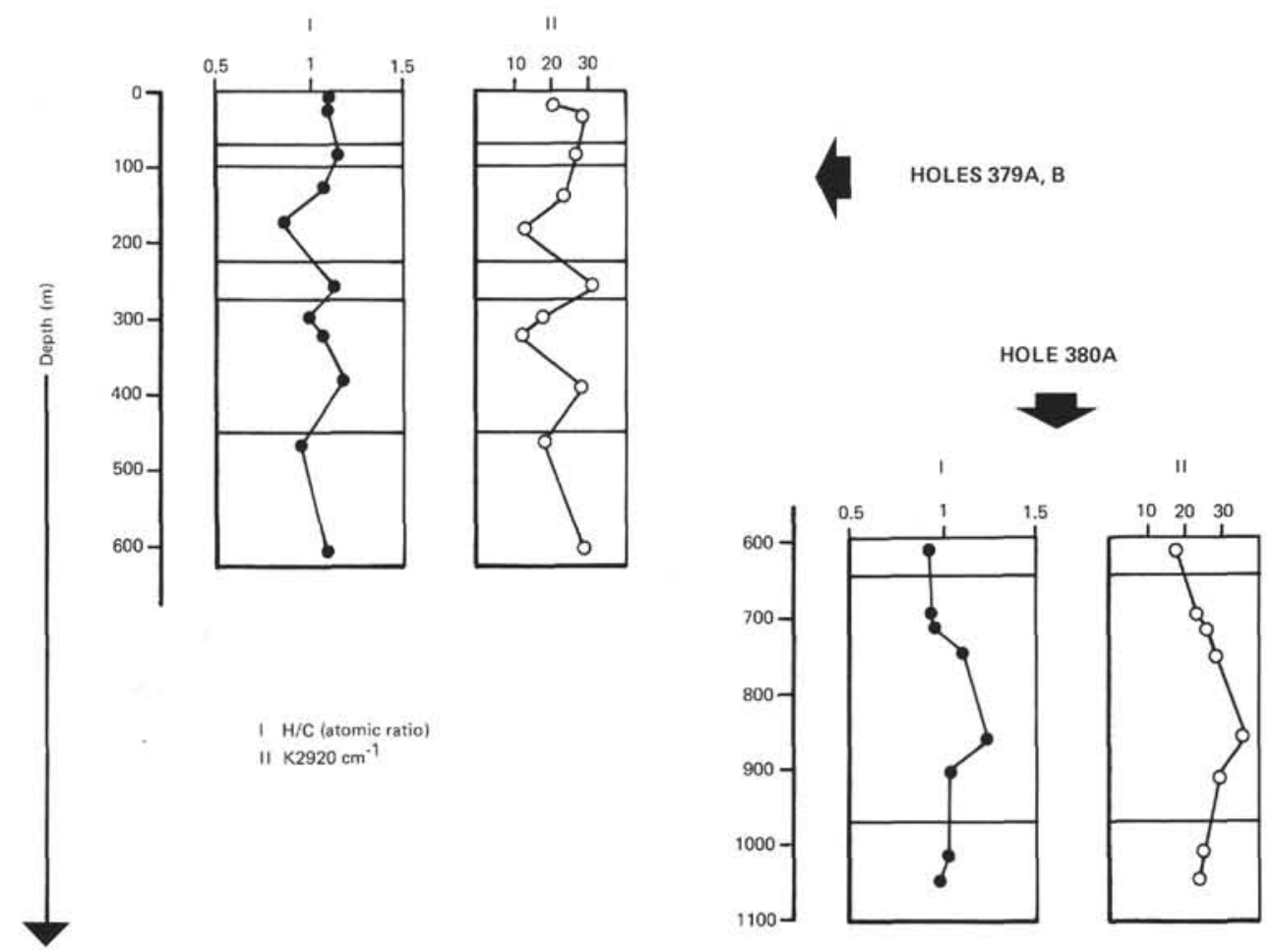

Figure 11. Variations in $\mathrm{H} / \mathrm{C}$ ratio and absorption measurement $K 2920 \mathrm{~cm}^{-1}$ values.

TABLE 7

Elemental Analysis of Kerogens

\begin{tabular}{|c|c|c|c|c|c|c|c|c|}
\hline \multirow[b]{2}{*}{$\begin{array}{l}\text { Core- } \\
\text { Section }\end{array}$} & \multicolumn{2}{|c|}{ C } & \multirow[b]{2}{*}{$\begin{array}{l}\text { Atomic } \\
\text { Ratio } \\
(\mathrm{H} / \mathrm{C})\end{array}$} & \multirow[b]{2}{*}{$\begin{array}{l}\text { Atomic } \\
\text { Ratio } \\
(\mathrm{O} / \mathrm{C} \\
\left.\times 10^{2}\right)\end{array}$} & \multirow[b]{2}{*}{$\begin{array}{l}\text { Atomic } \\
\text { Ratio } \\
(\mathrm{N} / \mathrm{C} \\
\left.\mathrm{X} 10^{2}\right)\end{array}$} & \multirow[b]{2}{*}{$\begin{array}{c}\text { Atomic } \\
\text { Ratio } \\
\text { (Sorg/C } \\
\times 10^{2} \text { ) }\end{array}$} & \multicolumn{2}{|c|}{ Minerals } \\
\hline & $1^{\mathrm{a}}$ & $2^{b}$ & & & & & Pyrite & Others \\
\hline \multicolumn{9}{|c|}{ Hole 379B } \\
\hline 1.4 & 41.64 & 67.10 & 0.93 & 22.28 & 3.44 & 2.85 & 11.01 & 26.93 \\
\hline $1-4$ & 42.82 & 64.99 & 1.04 & 22.63 & 3.26 & 4.20 & 11.46 & 22.65 \\
\hline \multicolumn{9}{|c|}{ Hole $379 \mathrm{~A}$} \\
\hline $32-2$ & 41.37 & 68.60 & 0.81 & 22.32 & 2.59 & 2.32 & 3.96 & 35.85 \\
\hline $34, C C$ & 46.19 & 67.15 & 0.99 & 23.82 & 3.19 & 1.94 & 4.59 & 26.63 \\
\hline $42-4$ & 46.53 & 67.52 & 1.04 & 22.34 & 2.03 & 2.72 & 10.35 & 20.74 \\
\hline $51-0$ & 41.50 & 68.01 & 0.82 & 24.42 & 2.56 & 1.74 & 2.27 & 36.71 \\
\hline $67-1$ & 43.82 & 65.73 & 1.07 & 26.40 & 2.61 & 1.86 & 21.75 & 10.62 \\
\hline \multicolumn{9}{|c|}{ Hole $380 \mathrm{~A}$} \\
\hline $41-0$ & 60.12 & 69.07 & 1.27 & 19.22 & 3.05 & 1.90 & 10.01 & 2.82 \\
\hline $41-3$ & 60.98 & 69.79 & 1.26 & 18.66 & 3.17 & 1.59 & 7.46 & 5.17 \\
\hline $46-1$ & 51.04 & 70.49 & 1.30 & 18.88 & 3.44 & 0.68 & 23.51 & 4.01 \\
\hline $57, \mathrm{CC}$ & 48.77 & 68.66 & 1.38 & 18.19 & 2.92 & 2.44 & 25.65 & 3.06 \\
\hline
\end{tabular}

a Organic carbon content.

borganic carbon content on a mineral-free basis.

the Black Sea Basin, i.e., more terrestrial organic matter inputs alternate with more autochthonous inputs.

2) Organic matter has undergone transformation as a function of burial, especially as inferred by a decrease in the hydrolyzable portion of the organic matter towards a more resistant material. This is accompanied by a decrease in the fulvic-acid fraction, suggesting a humification process, and by an overall decrease in humic compounds suggesting changes in the hydrophylic functions responsible for the extractability.
3) Specific transformations might be related to the different kinds of organic matter. Terrestrial-derived organic matter can undergo burial with few transformations, but in the more autochthonous organic matter we observe a decrease in the oxygen content as a function of evolution. This fact suggests that a large proportion of the oxygen associated with the latter is included as labile groups.

4) All these changes lead the bulk of the organic matter towards the kerogen status that is found in ancient sediments.

From this point of view we might claim that the forming of kerogen is over in Site 380, while it is still occurring in the core from Site 379.

\section{REFERENCES}

Bordovskiy, O.K., 1965. Accumulation and transformation of organic substance in marine sediments: Marine Geol., v. 3 , p. $3-114$.

Bellamy, L.J., 1958. The infrared spectra of complex molecules, 2nd Ed.: New York (John Wiley).

Debyser, Y. and Pelet, R., in preparation. More organic geochemistry in Black Sea sediments.

Debyser, Y., Leblond, C., Dastillung, M., and Gudel, F., 1977. Etude géochimique de sédiments Marins et lacustres: Advances in organic géochem.

Debyser, Y., Pelet, R., and Dastillung, M., 1975. Géochimie organique de sédiments marins récents: Mer Noire, Baltique, Atlantique (Mauritanie): Adv. in Org. Geochem.

Dunoyer de Segonzac, G., 1969. Les minéraux argileux dans la diagenèse. Passage au métamorphisme: Thesis, U. of Strasbourg. 


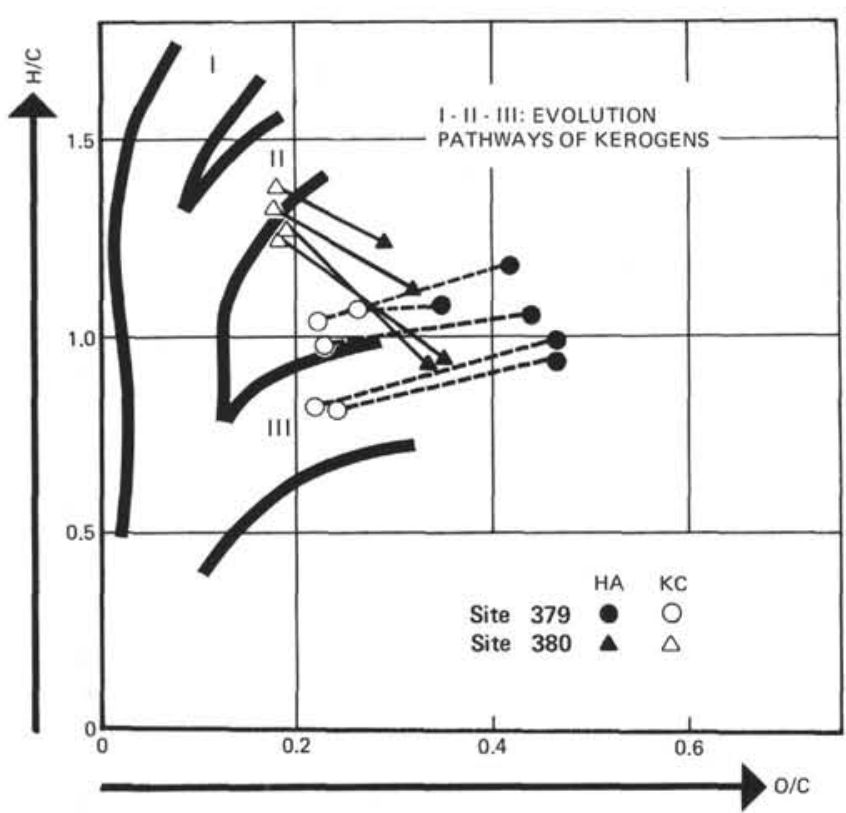

Figure 12. $H / C$ versus $O / C$ diagram - kerogens and associated humic acids.

Durand, B., Espitalié, J., Nicaise, G. and Combaz, A., 1972. Contribution à l'étude de la matière organique insoluble des sédimets anciens (kérognes) par différentes méthodes physicochiminques (lre partie): Rev. Inst. Franç. du Pétrole, v. 27. p. 865-884.
Gouleau, D., 1975. Les premiers stades de la sédimentation sur les vasières littorales: Thesis, U. of Nantes.

Huc, A.Y., 1973. Contribution à l'étude de l'humus marin et de ses relations avec les kérogènes: Thesis, U. of Nancy.

Huc, A.Y. and Durand, B., 1973. Etude des acides humiques et de l'humine de sédiments récents considérés comme précurseurs des kérogènes: Adv. in Org. Geochem., p. 5372.

, 1977. Occurrence and significance of humic acids in ancient sediments: Fuel, v. 56, p. 73-80.

Huc, A.Y., Durand, B., and Jacquin, F., 1974. Caractérisation des acides humiques de sédiments marins récents et comparaison avec leurs homologues terrestres: Bull. ENSAIA, Nancy, v. 16, p. 59-75.

Huc, A.Y., Roucaché, J., Bernon, M., Caillet, G. and Da Silva, M., 1976. Application de la chromatographie sur couche mince à l'étude quantitative et qualitative des extraits de roches et des huiles: Rev. Inst. Franc. du Pétrole, v. 31, p. 67-98.

Hunt, J., 1961. Distribution of hydrocarbons in sedimentary rocks: Geochim. Cosmochim. Acta, v. 22, p. 37-49.

Ishiwarati, R., 1967. Infrared Absorption band at $1540 \mathrm{~cm}-1$ of humic acids from a Recent lake sediment: Geochem. J. Japan, v. 1, p. 61-70.

, 1972. Transformation of sedimentary humic acids, facts and speculations: Int. Meet. Humic Substances Proc., Nieuwersluis Pudoc. Wagening en.

Klingebiel, A., Boltenhagen, C., Caratini, C., Debyser, Y., Delteil, J.R., Durand, B., Etienne, J., Huc, A.Y., Latouche, C., Millepieds, P., Parra, M., Pujol, C., Sauvan, P., and Sommer, F., 1975. Etudes stratigraphique, sédimentologique et géochimique de sédiments carottés
$379,20-2$

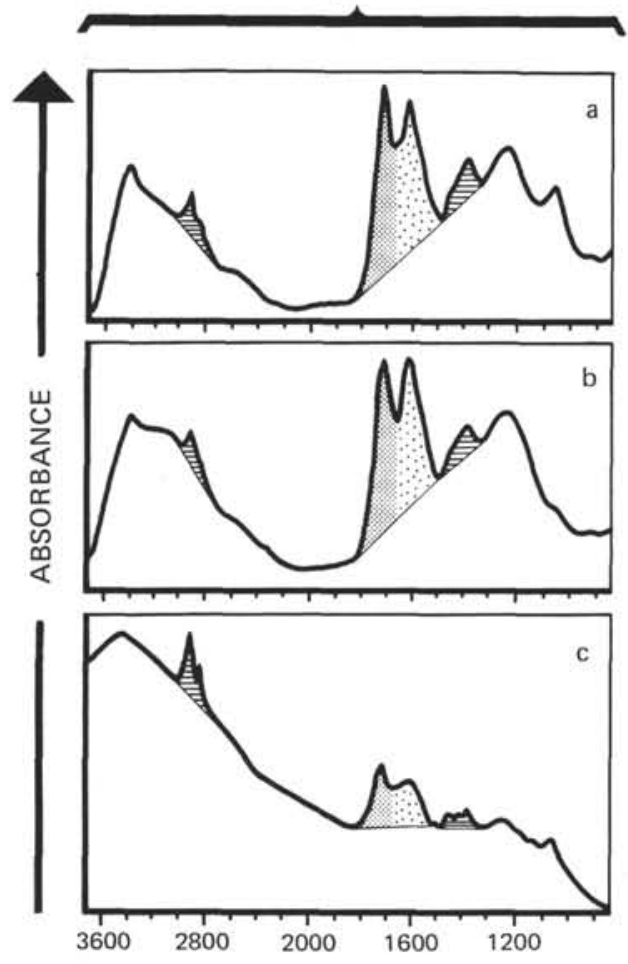

$379,42-4$
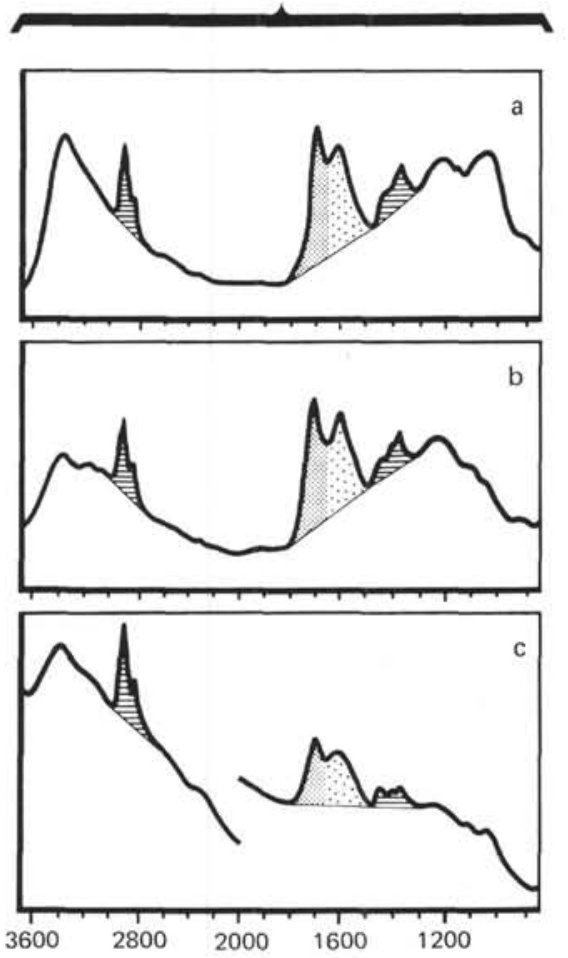

$380,57, \mathrm{CC}$
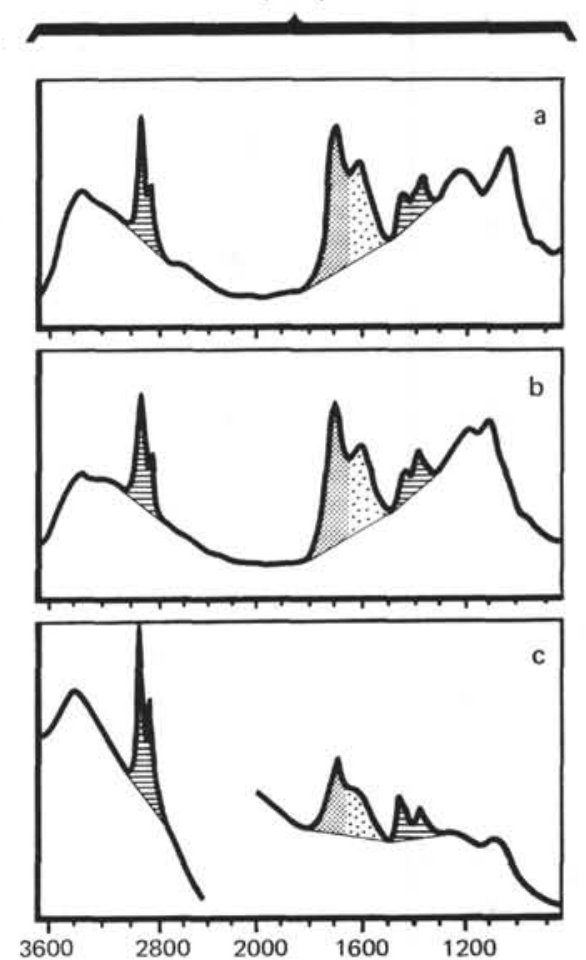

WAVE NUMBER CM${ }^{-1}$

a: Humic acids

b: Hydrolyzed humic acids

c: Kerogen

Figure 13. Infrared spectra of humic acids, hydrolyzed humic acids, and related kerogens. 


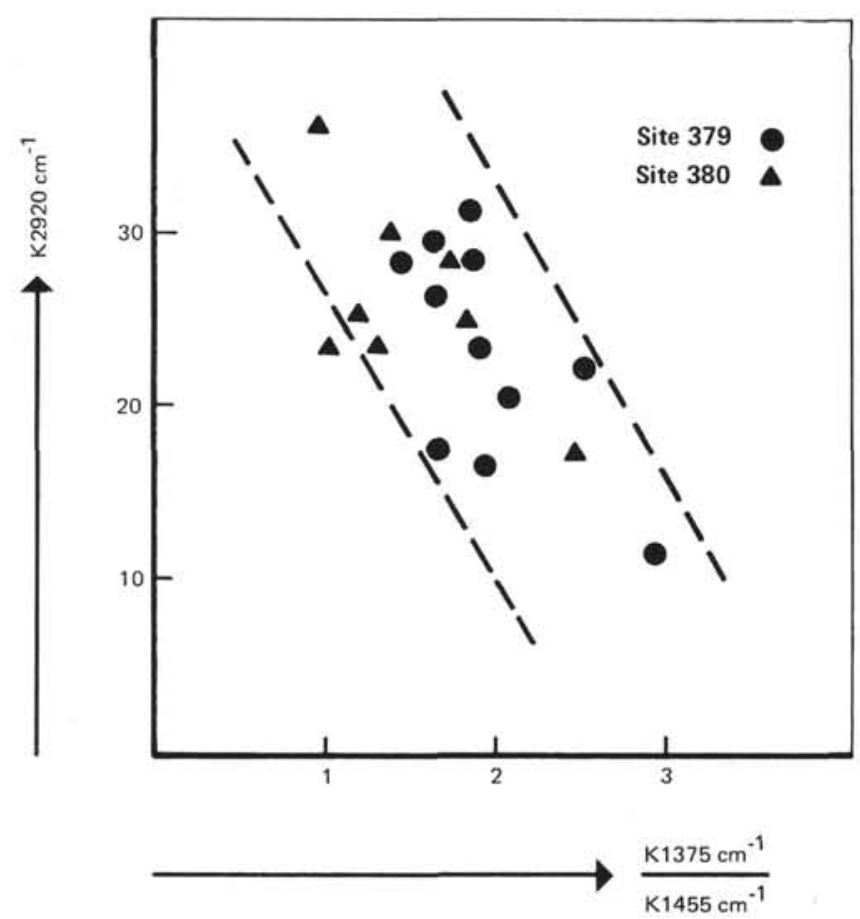

Figure 14. Relationship between absorption measurement $K 2920 \mathrm{~cm}_{-1}$ and $K 1375 / K 1455$ ratio in humic acids from Sites 379 and 380.

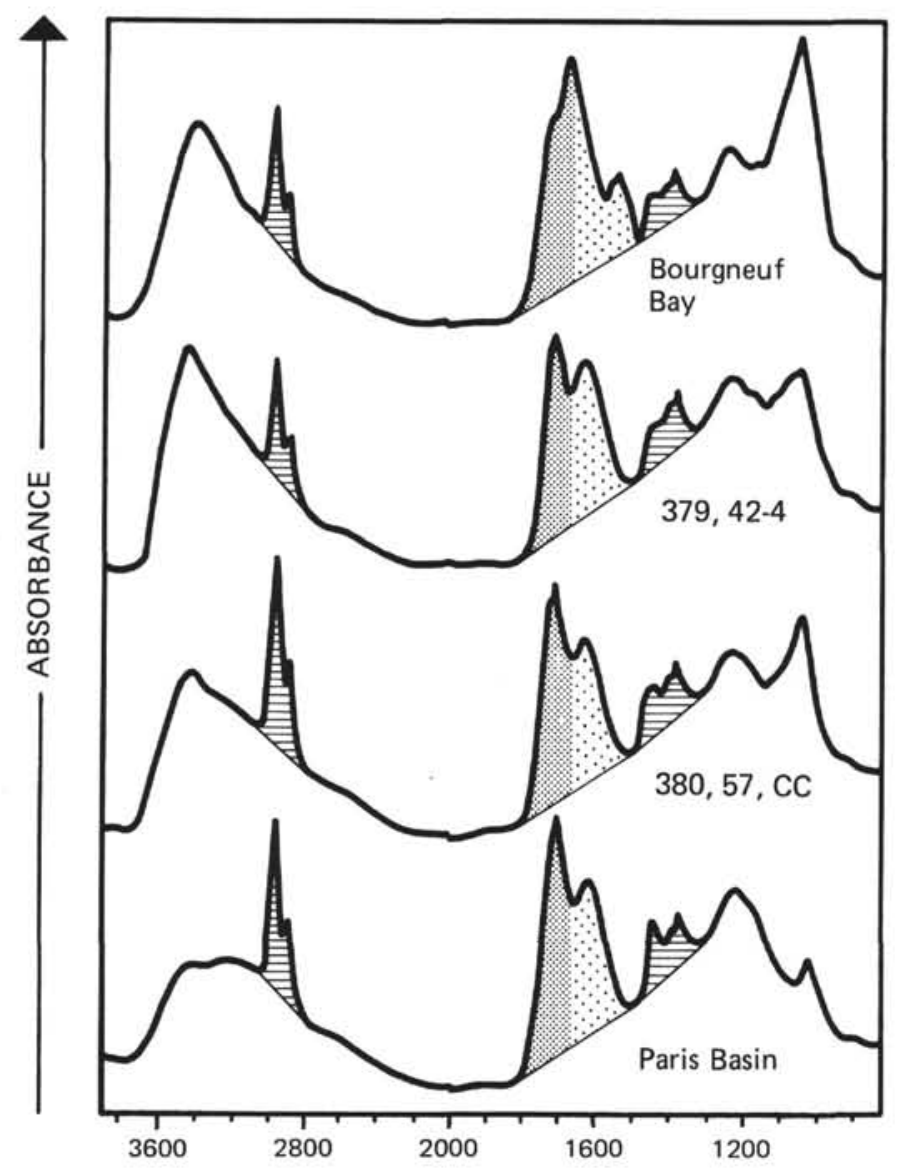

dans le Golfe de Guinée au cours de la campagne Bénin 1971: Bull. Inst. Géol. Bassin Aquitaine, v. 17, p. 101232.

Kononova, M.M. and Bel'Chikova, N.P., 1960. A study of soil humus substances by fractionation: Pochvovedeniye, v. 11, p. 1 .

Nissenbaum, A., Baedecker, M.J., and Kaplan, R., 1972. Organic Geochemistry of Dead Sea Sediments: Geochim. Cosmochim. Acta, v. 36, p. 709-727.

Rashid, M.A. and King, L.H., 1970. Major oxygen containing functional groups in humic and fulvic acid fractions isolated from contrasting marine environments: Geochim. Cosmochim. Acta, v. 34, p. 193-201.

Robin, P.L. and Rouxhet, P.G., 1976. Contribution of molecular water in the infrared spectra of kerogen and coals: Fuel, v. 55, p. 177-183.

Robin, P.L., Rouxhet, P.G., and Durand, B., in press. Caractérisation des kérogènes et de leur évolution par spectroscopie infra rouge: Adv. in Org. Geochem.

Stevenson, F.J. and Goth, K.M., 1971. Infrared spectra of humic acids and related substances: Geochim. Cosmochim. Acta, v. 35, p. 471-483.

Shimkus, K.M. and Trimonis, E.S., 1974. Modern sedimentation in the Black Sea. In Degens, E.T., Ross, D.A. (Eds.), The Black Sea-geology, chemistry and biology: Am. Assoc. Petrol. Geol. Mem. 20.

Tissot, B., Califet-Debyser, Y., Deroo, G., and Oudin, J.L., 1971. Origin and evolution of hydrocarbons in early Toarcian shales: France (Paris Basin), Bull. Am. Assoc. Petrol. Geol., v. 55, p. 2177.

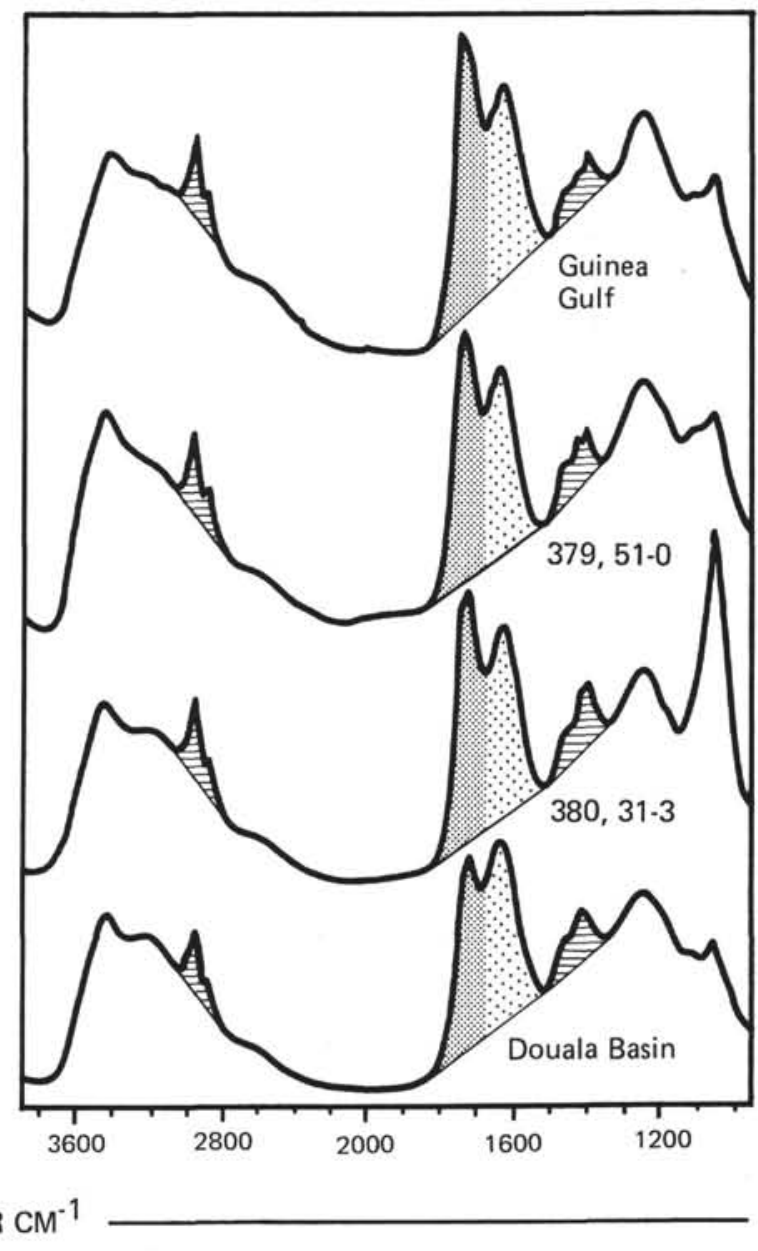

Figure 15. Infrared spectra of humic acids from Sites 379 and 380, comparison with humic acids from well-known deposititional environments. 